\title{
Distribution of Myctophidae (Pisces, Myctophiformes) during the four seasons in the mid North Atlantic
}

\author{
S. van der Spoel \& J. Bleeker \\ Institute of Taxonomic Zoology, University of Amsterdam, P.O. Box 4766, 1009 AT Amsterdam, \\ The Netherlands
}

Keywords: Myctophidae, biogeography, North Atlantic, faunal borders

\begin{abstract}
The distribution, temperature, and size ranges of 60 species of myctophids in the North Atlantic between $55^{\circ} \mathrm{N}$ and $24^{\circ} \mathrm{N}$ along approximately $30^{\circ} \mathrm{W}$ are recorded for the four seasons. The general zoogeography and migration is discussed. Faunal groups of species, faunal borders, and transition zones near $50^{\circ} \mathrm{N}$, $41^{\circ} \mathrm{N}$, and $29^{\circ} \mathrm{N}$ for myctophids are distinguished and discussed.
\end{abstract}

\section{Résumé}

Ont été enregistrées, pendant les quatre saisons, la distribution, les températures et les limites de la taille pour 60 espèces de Myctophidés dans l'Atlantique Nord entre $55^{\circ} \mathrm{N}$ et $24^{\circ} \mathrm{N}$, approximativement à $30^{\circ} \mathrm{O}$. Sont discutés des aspects tels que la distribution générale et les migrations. Sont distingués des groupements d'espèces, des limites faunistiques, et des zones de transition pour les Myctophidés au voisinage de $50^{\circ} \mathrm{N}, 41^{\circ} \mathrm{N}$ et $29^{\circ} \mathrm{N}$; tous ces aspects sont discutés.

\section{Introduction}

This paper deals with the Myctophidae collected by the Amsterdam Mid North Atlantic Plankton Expeditions 1980, 1981, 1982, and 1983. The material was collected along approximately $30^{\circ} \mathrm{W}$ between $55^{\circ} \mathrm{N}$ and $24^{\circ} \mathrm{N}$ and along $25^{\circ} \mathrm{N}$ between $20^{\circ} \mathrm{W}$ and $30^{\circ} \mathrm{W}$ in the upper $1000 \mathrm{~m}$ with the combined Rectangular Midwater Trawl (RMT 1+8), in the periods April 11-May 2, 1980; September 13-October 16, 1981; February 9-21, 1982, and May 29-June 18,1983 . The cruise of 1980 is considered a spring cruise, that of 1983 a summer, of 1981 an autumn, and of 1982 a winter cruise. The hauls were usually made during each season at nearly the same localities. Some additional open net hauls from the upper $170 \mathrm{~m}$ and discrete samples down to $2000 \mathrm{~m}$ were used. For locality data, hydrographic measurements, and description of the gear, see Van der Spoel $(1981,1985)$ and Van der Spoel \& Meerding (1983).

Myctophidae, known as rather strictly bound to marine provinces and water masses (Backus et al., 1965; Backus \& Craddock, 1977), were studied to obtain indications of biogeographic boundaries in the area investigated. Although the sampling programme was not suitable to study diurnal vertical migration, for some species indications of such a migration could be reported. In total 477 myctophid specimens, from a total of 14135 , could not be identified and are left out of consideration here. Mainly Bolin (1955), Gibbs et al. (1971), Napfaktitis (1968, 1975), Nafpaktitis \& Paxton (1968), Nafpaktitis et al. (1977), and Hulley (1984) were used for identification.

\section{Remarks on some of the species}

Species are listed below with comments, in alphabetic order; for data on the material and localities see Table I and Figs. 1-2.

Benthosema glaciale. In spring this boreo-arctic species penetrates as far south as $35^{\circ} \mathrm{N}$. From 
Table I. Material collected $\left(^{*}=\right.$ twilight samples excluded; Sp. $=$ spring, Su. $=$ summer, A. $=$ autumn, W. $=$ winter $)$.

\begin{tabular}{|c|c|c|c|c|c|c|c|}
\hline Species & Season & $\begin{array}{l}\text { Temp. } \\
\left({ }^{\circ} \mathrm{C}\right) \text { range } \\
\text { day time* }\end{array}$ & $\begin{array}{l}\text { Temp. } \\
\left({ }^{\circ} \mathrm{C}\right) \\
\max .\end{array}$ & $\begin{array}{l}\text { Size } \\
\text { range } \\
(\mathrm{cm})\end{array}$ & $\begin{array}{l}\text { Depth day } \\
\text { range* }\end{array}$ & $\begin{array}{l}\text { Depth night } \\
\text { range* }\end{array}$ & $\begin{array}{l}N \text {. of } \\
\text { speci- } \\
\text { mens }\end{array}$ \\
\hline \multicolumn{8}{|l|}{ NORTH of $50^{\circ} \mathrm{N}$} \\
\hline Protomyctophum arcticum & Sp. & $5.00-6.90$ & 10.9 & $1.33-4.09$ & $40-995$ & $215-400$ & 181 \\
\hline \multirow{2}{*}{ (Lütken, 1892) } & Su. & $5.35-10.05$ & 10.1 & $1.60-4.39$ & $200-400$ & - & 344 \\
\hline & A. & $4.15-9.50$ & 11.9 & $1.60-5.29$ & $300-1000$ & - & 159 \\
\hline Benthosema glaciale & Sp. & $4.45-14.20$ & 17.2 & $1.50-6.61$ & $265-1010$ & $0-400$ & 1488 \\
\hline \multirow{2}{*}{ (Reinhardt, 1837) } & Su. & $4.45-12.90$ & 15.5 & $1.10-7.04$ & $200-995$ & $0-105,1000-1750$ & 1243 \\
\hline & A. & $4.15-11.95$ & 15.9 & $1.15-6.79$ & $300-1020$ & $0-100$ & 2868 \\
\hline Myctophum punctatum & Sp. & $6.70-10.40$ & 15.5 & $1.01-9.01$ & $440-1005$ & $40-100$ & 17 \\
\hline \multirow[t]{2}{*}{ Rafinesque, 1810} & $\mathrm{Su}$. & $5.95-10.05$ & 18.0 & $1.02-6.08$ & $200-398,500-995$ & $0-105$ & 196 \\
\hline & A. & 6.90 & 17.5 & $1.99-5.95$ & $500-1020$ & $0-100$ & 57 \\
\hline Notoscopelus kroeyeri & Sp. & $4.45-5.95$ & 10.9 & $5.30-13.64$ & $265-1010$ & $40-100,210-310$ & 12 \\
\hline \multirow[t]{2}{*}{ (Malm, 1861) } & $\mathrm{Su}$. & $9.45-11.90$ & 21.4 & $1.47-6.54$ & $300-5403$ & $0-150$ & 246 \\
\hline & A. & $4.75-9.50$ & 9.8 & $3.75-6.50$ & $300-400$ & $0-100$ & 19 \\
\hline \multicolumn{8}{|c|}{ BETWEEN $50^{\circ}$ AND $41^{\circ} \mathrm{N}$} \\
\hline Notoscopelus bolini & Sp. & $9.85-10.50$ & 10.5 & $2.20-2.55$ & $440-1000$ & - & 12 \\
\hline \multirow[t]{2}{*}{ Nafpaktitis, 1975} & Su. & - & 20.3 & $2.23-6.72$ & - & $0-105$ & 36 \\
\hline & A. & $7.25-10.00$ & 15.2 & $6.00-6.45$ & $405-500$ & $55-100$ & 7 \\
\hline Lampanyctus crocodilus & Sp. & $5.00-9.85$ & 13.5 & $4.66-9.06$ & $480-1005$ & $50-200$ & 9 \\
\hline \multirow[t]{2}{*}{ (Risso, 1810) } & Su. & - & 16.8 & $2.20-3.21$ & - & $0-210$ & 56 \\
\hline & A. & $9.70-10.25$ & 15.2 & $3.10-12.50$ & $460-1010$ & $45-100,425-855$ & 13 \\
\hline \multirow{3}{*}{$\begin{array}{l}\text { Lampanyctus macdonaldi } \\
\text { (Goode \& Bean, 1896) }\end{array}$} & Sp. & 5.00 & 5.0 & 12.88 & $290-995$ & - & 1 \\
\hline & Su. & - & 16.9 & $2.33-6.60$ & - & $45-150$ & 18 \\
\hline & A. & - & 15.9 & $4.05-7.80$ & - & $0-190$ & 2 \\
\hline \multicolumn{8}{|c|}{ BETWEEN $41^{\circ}$ and $29^{\circ} \mathrm{N}$} \\
\hline Lampadena chavesi & Sp. & - & 18.2 & $2.43-5.77$ & - & $90-205$ & 5 \\
\hline \multirow{3}{*}{ Collett, 1905} & Su. & 9.65 & 19.2 & $2.15-6.66$ & $7.52-1005$ & $55-200$ & 7 \\
\hline & A. & $9.80-11.75$ & 19.4 & $2.10-2.90$ & $490-1175$ & $50-230,270-395$ & 8 \\
\hline & $\mathbf{W}$ & - & 15.3 & $1.40-3.69$ & - & $195-302$ & 9 \\
\hline Lampanyctus festivus & Sp. & 10.25 & 18.2 & $3.51-8.11$ & $500-1000$ & $45-300$ & 5 \\
\hline \multirow[t]{3}{*}{ Tảning, 1928} & Su. & - & 20.3 & $3.05-8.02$ & - & $0-50,98-200$ & 6 \\
\hline & A. & - & 19.8 & $2.60-7.95$ & - & $45-300$ & 88 \\
\hline & W. & - & 19.2 & $1.32-5.23$ & - & $40-305$ & 41 \\
\hline \multicolumn{8}{|c|}{ BETWEEN $50^{\circ}$ and $29^{\circ} \mathrm{N}$} \\
\hline Lampanyctus pusillus & Sp. & $4.45-10.50$ & 19.5 & $1.49-3.98$ & $480-1010$ & $40-205$ & 293 \\
\hline \multirow[t]{3}{*}{ (Johnson, 1890) } & Su. & $8.60-11.90$ & 20.3 & $1.19-3.99$ & $400-1000$ & $0-210$ & 691 \\
\hline & A. & $6.90-12.25$ & 21.9 & $1.40-3.80$ & $385-1020$ & $0-230$ & 240 \\
\hline & W. & - & 15.3 & $2.02-3.93$ & - & $0-150$ & 22 \\
\hline Diaphus rafinesquei & Sp. & $10.50-14.20$ & 17.9 & $1.88-8.52$ & $280-1000$ & $40-1000$ & 203 \\
\hline \multirow[t]{3}{*}{ (Cocco, 1838) } & Su. & $9.95-11.90$ & 19.0 & $1.99-8.05$ & $300-503$ & $0-528$ & 101 \\
\hline & A. & $6.90-12.85$ & 15.2 & $1.61-8.59$ & $310-1020$ & $55-100,195-1050$ & 128 \\
\hline & w. & $10.30-14.75$ & 15.6 & $1.61-8.30$ & $400-980$ & $195-1010$ & 39 \\
\hline Diaphus holti & Sp. & 7.75 & 16.0 & $2.42-5.00$ & $205-300$ & $50-320$ & 57 \\
\hline \multirow[t]{3}{*}{ Tảning, 1918} & Su. & 13.70 & 14.9 & $3.28-4.65$ & $200-300$ & $205-305$ & 23 \\
\hline & A. & $4.75-14.10$ & 19.8 & $1.06-4.90$ & $300-570$ & $0-230$ & 25 \\
\hline & W. & - & 18.6 & $1.80-4.18$ & - & $0-190$ & 4 \\
\hline Diaphus metopoclampus & Sp. & $10.20-13.50$ & 15.0 & $1.16-6.88$ & $360-1000$ & $265-1130$ & 19 \\
\hline \multirow[t]{2}{*}{ (Cocco, 1829) } & Su. & $11.90-11.90$ & 14.4 & $2.04-7.06$ & $400-503$ & $280-400$ & 25 \\
\hline & A. & $10.00-12.25$ & 12.5 & $3.05-4.85$ & $385-565$ & - & 10 \\
\hline Hygophum hygomi & Sp. & $10.35-13.70$ & 19.5 & $1.45-4.36$ & $280-1000$ & $40-205$ & 24 \\
\hline \multirow[t]{3}{*}{ (Lütken, 1892) } & Su. & 10.00 & 21.7 & $1.55-4.26$ & $494-1000$ & $0-105$ & 17 \\
\hline & A. & 9.15 & 9.2 & $3.80-4.50$ & $570-1000$ & - & 2 \\
\hline & W. & - & 15.3 & $1.53-1.76$ & - & $0-10$ & 5 \\
\hline
\end{tabular}


Table I. Continuation.

\begin{tabular}{|c|c|c|c|c|c|c|c|}
\hline Species & Season & $\begin{array}{l}\text { Temp. } \\
\left({ }^{\circ} \mathrm{C}\right) \text { range } \\
\text { day time* }\end{array}$ & $\begin{array}{l}\text { Temp. } \\
\left({ }^{\circ} \mathrm{C}\right) \\
\max .\end{array}$ & $\begin{array}{l}\text { Size } \\
\text { range } \\
(\mathrm{cm})\end{array}$ & $\begin{array}{l}\text { Depth day } \\
\text { range* }\end{array}$ & $\begin{array}{l}\text { Depth night } \\
\text { range* }\end{array}$ & $\begin{array}{l}N . \text { of } \\
\text { speci- } \\
\text { mens }\end{array}$ \\
\hline Notolychnus valdiviae & Sp. & $10.35-13.90$ & 21.4 & $0.99-2.31$ & $280-1000$ & $40-220$ & 147 \\
\hline \multirow[t]{3}{*}{ (Brauer, 1904) } & Su. & $10.00-13.70$ & 21.7 & $0.99-2.30$ & $300-1000$ & $0-205,300-400$ & 161 \\
\hline & A. & $6.90-11.75$ & 21.1 & $1.30-2.50$ & $385-1020$ & $30-105$ & 21 \\
\hline & W. & - & 19.2 & $1.38-2.25$ & - & $40-115$ & 22 \\
\hline Gonichthys coccoi & Sp. & $10.25-13.30$ & 19.1 & $1.85-4.72$ & $420-1000$ & $45-205$ & 12 \\
\hline \multirow[t]{3}{*}{ (Cocco, 1829) } & Su. & $9.90-11.90$ & 20.3 & $1.91-4.60$ & $400-1503$ & $0-205$ & 10 \\
\hline & A. & $10.25-12.25$ & 18.7 & $2.00-4.40$ & $460-870$ & $110-195$ & 12 \\
\hline & W. & - & 18.6 & $2.00-2.78$ & - & $80-190$ & 5 \\
\hline Lampanyctus ater & Sp. & $9.85-10.40$ & 16.5 & $1.15-10.90$ & $440-1000$ & $45-100$ & 71 \\
\hline \multirow[t]{3}{*}{ Tảning, 1928} & Su. & $9.45-10.00$ & 20.7 & $1.74-9.55$ & $300-398,494-1000$ & $45-400$ & 55 \\
\hline & A. & $6.90-10.25$ & 19.8 & $3.40-10.80$ & $460-1020$ & $45-300,425-855$ & 36 \\
\hline & W. & - & 18.6 & $0.89-3.10$ & - & $80-305$ & 11 \\
\hline Lampanyctus intricarius & Sp. & - & 16.5 & $5.15-5.95$ & - & $85-220$ & 4 \\
\hline \multirow[t]{3}{*}{ Tảning, 1928} & Su. & 10.00 & 18.1 & $2.45-5.04$ & $494-1000$ & $50-98$ & 5 \\
\hline & A. & $4.15-6.90$ & 17.5 & $3.10-7.59$ & $400-1020$ & $0-230$ & 8 \\
\hline & W. & 10.30 & 10.3 & $2.13-2.82$ & $505-980$ & - & 4 \\
\hline \multicolumn{8}{|l|}{ SOUTH OF $50^{\circ}$ NORTH } \\
\hline \multirow{3}{*}{$\begin{array}{l}\text { Symbolophorus veranyi } \\
\text { (Moreau, 1888) }\end{array}$} & Sp. & $10.25-10.50$ & 14.0 & $2.19-9.81$ & $500-1000$ & $50-100,265-430$ & 7 \\
\hline & Su. & - & 20.3 & $2.28-10.85$ & - & $0-100$ & 51 \\
\hline & A. & - & 19.3 & $2.40-8.90$ & - & $40-105$ & 10 \\
\hline & Sp. & $7.75-14.20$ & 21.5 & $0.97-4.16$ & $205-1000$ & $0-320$ & 400 \\
\hline \multirow[t]{3}{*}{ (Zugmayer, 1911) } & Su. & $4.90-16.70$ & 21.7 & $1.05-3.92$ & $295-1000$ & $0-205$ & 448 \\
\hline & A. & $9.50-14.10$ & 19.8 & $1.45-3.95$ & $205-870$ & $0-230$ & 225 \\
\hline & W. & 14.75 & 19.2 & $1.54-3.55$ & $110-430$ & $40-115$ & 28 \\
\hline Bolinichthys indicus & Sp. & $9.80-11.00$ & 21.4 & $1.30-4.04$ & $440-1090$ & $40-205$ & 174 \\
\hline \multirow{3}{*}{$\begin{array}{l}\text { Nafpaktitis \& Nafpaktitis, } \\
1969\end{array}$} & Su. & $9.65-10.00$ & 20.7 & $1.45-4.55$ & $494-1005$ & $45-305$ & 137 \\
\hline & A. & $9.15-11.75$ & 21.1 & $1.15-3.90$ & $490-1005$ & $30-230$ & 83 \\
\hline & W. & - & 19.2 & $1.27-3.84$ & - & $40-305$ & 54 \\
\hline \multirow{4}{*}{$\begin{array}{l}\text { Lobianchia gemellarii } \\
\text { (Cocco, 1838) }\end{array}$} & Sp. & $9.80-15.10$ & 21.5 & $1.20-8.20$ & $280-1510$ & $40-205,265-505$ & 96 \\
\hline & Su. & $8.60-16.70$ & 21.7 & $1.36-8.22$ & $390-518$ & $0-305$ & 50 \\
\hline & A. & $6.90-19.15$ & 23.0 & $1.80-6.90$ & $310-1020$ & $30-100,195-410$ & 33 \\
\hline & W. & 13.85 & 18.6 & $1.22-3.84$ & $400-490$ & $40-190$ & 29 \\
\hline \multirow{4}{*}{$\begin{array}{l}\text { Electrona rissoi } \\
\text { (Cocco, 1829) }\end{array}$} & Sp. & 12.35 & 16.5 & $0.86-4.81$ & $280-410$ & $80-305$ & 6 \\
\hline & Su. & - & 14.9 & $0.95-2.42$ & - & - & 22 \\
\hline & A. & - & 16.3 & 1.41 & - & $200-325$ & 1 \\
\hline & W. & - & 15.3 & $1.18-1.73$ & - & $195-305$ & 3 \\
\hline \multicolumn{8}{|l|}{ SOUTH OF $41^{\circ}$ NORTH } \\
\hline \multirow{3}{*}{$\begin{array}{l}\text { Notoscopelus resplendens } \\
\text { (Richardson, 1845) }\end{array}$} & Sp. & 8.25 & 19.1 & $2.11-6.15$ & $770-1250$ & $40-300$ & 10 \\
\hline & Su. & - & 20.7 & $2.41-3.17$ & - & $50-105$ & 25 \\
\hline & A. & - & 19.3 & $2.30-4.60$ & - & $40-105$ & 3 \\
\hline \multirow{4}{*}{$\begin{array}{l}\text { Diogenichthys laternatus } \\
\text { atlanticus (Tåning, 1928) }\end{array}$} & Sp. & 10.25 & 19.5 & $1.45-2.27$ & $500-1000$ & $0-110$ & 16 \\
\hline & Su. & 10.00 & 21.7 & $1.02-2.28$ & $494-1000$ & $0-210$ & 166 \\
\hline & A. & - & 19.4 & $1.30-1.90$ & - & $40-300$ & 15 \\
\hline & W. & 10.30 & 15.3 & $1.20-2.13$ & $505-980$ & $40-100$ & 6 \\
\hline \multirow{4}{*}{$\begin{array}{l}\text { Diaphus mollis } \\
\text { Tảning, } 1928\end{array}$} & Sp. & $9.80-14.20$ & 21.4 & $1.11-4.92$ & $285-1090$ & $40-205$ & 78 \\
\hline & Su. & $13.70-16.70$ & 21.7 & $1.12-5.22$ & $390-532$ & $0-305$ & 21 \\
\hline & A. & $11.75-12.85$ & 21.1 & $1.10-4.40$ & $390-745$ & $30-300$ & 23 \\
\hline & W. & - & 18.6 & $2.97-4.91$ & - & $40-190$ & 6 \\
\hline
\end{tabular}


Table I. Continuation.

\begin{tabular}{|c|c|c|c|c|c|c|c|}
\hline Species & Season & $\begin{array}{l}\text { Temp. } \\
\left({ }^{\circ} \mathrm{C}\right) \text { range } \\
\text { day time* }\end{array}$ & $\begin{array}{l}\text { Temp. } \\
\left({ }^{\circ} \mathrm{C}\right) \\
\max .\end{array}$ & $\begin{array}{l}\text { Size } \\
\text { range } \\
(\mathrm{cm})\end{array}$ & $\begin{array}{l}\text { Depth day } \\
\text { range* }\end{array}$ & $\begin{array}{l}\text { Depth night } \\
\text { range* }\end{array}$ & $\begin{array}{l}N . \text { of } \\
\text { speci- } \\
\text { mens }\end{array}$ \\
\hline Lampanyctus photonotus & Sp. & $8.25-10.90$ & 21.4 & $2.32-5.96$ & $475-1250$ & $40-250$ & 68 \\
\hline \multirow[t]{3}{*}{ Parr, 1928} & Su. & 10.00 & 20.7 & $1.46-6.61$ & $494-1000$ & $0-205$ & 174 \\
\hline & A. & 9.85 & 23.3 & $1.80-6.05$ & $490-1005$ & $30-230$ & 36 \\
\hline & w. & - & 15.6 & $1.70-4.50$ & - & - & 20 \\
\hline \multirow{4}{*}{$\begin{array}{l}\text { Ceratoscopelus warmingii } \\
\text { (Lütken, 1892) }\end{array}$} & $\mathrm{Sp}$. & $8.25-10.50$ & 21.5 & $1.09-6.96$ & $475-1250$ & $40-300$ & 178 \\
\hline & Su. & - & 21.7 & $1.07-6.64$ & - & $0-205$ & 104 \\
\hline & A. & $9.80-9.85$ & 23.0 & $1.55-6.00$ & $490-1010$ & $0-230$ & 222 \\
\hline & W. & 14.75 & 19.2 & $1.66-3.35$ & $110-430$ & $40-115$ & 22 \\
\hline \multirow{3}{*}{$\begin{array}{l}\text { Benthosema suborbitale } \\
\text { (Gilbert, 1913) }\end{array}$} & Sp. & $9.80-13.30$ & 21.5 & $1.18-2.91$ & $420-1090$ & $40-110$ & 100 \\
\hline & Su. & - & 21.7 & $1.19-4.54$ & - & $0-105,395-528$ & 127 \\
\hline & A. & - & 21.1 & $1.30-2.70$ & - & $30-105$ & 19 \\
\hline \multirow{4}{*}{$\begin{array}{l}\text { Ceratoscopelus maderensis } \\
\text { (Lowe, 1839) }\end{array}$} & Sp. & - & 17.2 & $4.15-7.44$ & - & $40-110$ & 27 \\
\hline & Su. & - & 21.4 & $1.46-5.78$ & - & $50-98$ & 34 \\
\hline & A. & $9.80-11.75$ & 21.1 & $1.30-3.00$ & $385-1010$ & $30-105$ & 41 \\
\hline & W. & - & 19.2 & $1.75-3.12$ & - & $40-115$ & 10 \\
\hline Lampanyctus lineatus & Sp. & 10.40 & 10.4 & 10.23 & $440-910$ & - & 1 \\
\hline \multirow[t]{3}{*}{ Tåning, 1928} & $\mathrm{Su}$. & 9.65 & 21.7 & $1.72-6.66$ & $752-1005$ & $0-210$ & 27 \\
\hline & A. & - & 16.3 & $4.45-5.20$ & - & $95-380,425-855$ & 3 \\
\hline & $\mathbf{w}$ & 10.30 & 10.3 & $1.72-10.22$ & $505-980$ & $490-1010$ & 8 \\
\hline Lampadena urophaos & Sp. & $8.25-10.50$ & 19.9 & $1.91-5.57$ & $490-1250$ & $100-200,510-1000$ & 11 \\
\hline \multirow[t]{3}{*}{ Paxton, 1963} & Su. & 5.95 & 20.3 & $2.13-7.55$ & $500-990$ & $95-210$ & 9 \\
\hline & A. & - & 19.3 & 9.10 & - & $40-105$ & 1 \\
\hline & W. & - & 18.6 & $2.02-2.13$ & - & $80-305$ & 2 \\
\hline Lepidophanes gaussi & Sp. & $9.80-11.00$ & 21.5 & $1.69-4.51$ & $490-1090$ & $40-205$ & 35 \\
\hline \multirow[t]{3}{*}{ (Brauer, 1906) } & Su. & 9.65 & 21.7 & $1.85-4.48$ & $752-1005$ & $0-50,98-200$ & 35 \\
\hline & A. & 11.75 & 23.1 & $1.50-3.00$ & $385-570$ & $40-105,270-395$ & 13 \\
\hline & $\mathbf{W}$ & - & 14.7 & $2.52-5.84$ & - & - & 3 \\
\hline Lowenia rara & Sp. & - & 18.2 & $2.64-3.32$ & - & $90-205$ & 6 \\
\hline \multirow[t]{2}{*}{ (Lütken, 1892) } & Su. & - & 20.3 & 2.89 & - & - & 1 \\
\hline & A. & - & 18.7 & 2.15 & - & $110-195$ & 1 \\
\hline Lampanyctus cuprarius & Sp. & $9.80-10.50$ & 17.1 & $3.52-7.22$ & $490-1090$ & $100-405,510-1000$ & 17 \\
\hline \multirow[t]{2}{*}{ Tåning, 1928} & $\mathrm{Su}$. & 4.45 & 20.3 & $2.34-7.24$ & $490-995$ & $50-105,200-305$ & 16 \\
\hline & A. & - & 19.8 & $4.60-7.30$ & - & $45-325$ & 19 \\
\hline \multicolumn{8}{|l|}{ SOUTH OF $29^{\circ}$ NORTH } \\
\hline Hygophum taaningi & Sp. & $9.80-10.50$ & 21.2 & $1.31-4.59$ & $475-1090$ & $40-205$ & 17 \\
\hline \multirow[t]{3}{*}{ Becker, 1965} & Su. & - & 21.4 & $1.65-3.32$ & - & - & 5 \\
\hline & A. & $9.15-9.85$ & 23.0 & $1.60-4.34$ & $490-1005$ & $30-105$ & 27 \\
\hline & W. & - & 14.8 & $2.64-3.66$ & - & $515-995$ & 3 \\
\hline \multicolumn{8}{|c|}{ INCIDENTALLY COLLECTED } \\
\hline Diaphus brachycephalus & Sp. & - & 17.0 & $1.11-3.49$ & - & - & 2 \\
\hline Tåning, 1928 & $\mathrm{Su}$. & 19.30 & 20.3 & $3.90-4.12$ & $105-200$ & - & 2 \\
\hline \multicolumn{8}{|l|}{ Diaphus bertelseni } \\
\hline Nafpaktitis, 1966 & W. & - & 8.6 & 7.70 & - & $505-1000$ & 1 \\
\hline Diaphus effulgens & Sp. & - & 9.0 & 9.84 & - & - & 1 \\
\hline \multirow[t]{3}{*}{ (Goode \& Bean, 1896) } & Su. & 11.90 & 20.3 & $3.50-8.99$ & $400-503$ & $98-200$ & 5 \\
\hline & A. & $9.15-11.75$ & 16.3 & $2.75-7.10$ & $490-1000$ & $95-395$ & 4 \\
\hline & W. & - & 18.6 & $3.52-11.80$ & - & $80-190,515-995$ & 6 \\
\hline \multicolumn{8}{|l|}{ Diaphus fragilis } \\
\hline Tảning, 1928 & A. & 9.80 & 21.1 & $6.20-8.00$ & $490-1005$ & $30-92$ & 2 \\
\hline
\end{tabular}


Table I. Continuation.

\begin{tabular}{|c|c|c|c|c|c|c|c|}
\hline Species & Season & $\begin{array}{l}\text { Temp. } \\
\left({ }^{\circ} \mathrm{C}\right) \text { range } \\
\text { day time* }\end{array}$ & $\begin{array}{l}\text { Temp. } \\
\left({ }^{\circ} \mathrm{C}\right) \\
\max .\end{array}$ & $\begin{array}{l}\text { Size } \\
\text { range } \\
\text { (cm) }\end{array}$ & $\begin{array}{l}\text { Depth day } \\
\text { range* }\end{array}$ & $\begin{array}{l}\text { Depth night } \\
\text { range* }\end{array}$ & $\begin{array}{l}N \text {. of } \\
\text { speci- } \\
\text { mens }\end{array}$ \\
\hline Diaphus lucidus & Sp. & - & 19.4 & $2.03-6.59$ & - & $90-300$ & 3 \\
\hline \multirow[t]{2}{*}{ (Goode \& Bean, 1896) } & $\mathrm{Su}$ & - & 9.3 & 5.48 & - & - & 1 \\
\hline & A. & - & 16.3 & $7.30-8.40$ & - & $210-395$ & 2 \\
\hline \multicolumn{8}{|l|}{ Diaphus splendidus } \\
\hline (Brauer, 1904) & Su. & - & 20.3 & 7.83 & - & - & 1 \\
\hline Diaphus subtilus & Sp. & 10.35 & 10.4 & 7.44 & $475-1000$ & - & 1 \\
\hline \multirow[t]{2}{*}{ Nafpaktitis, 1968} & $\mathrm{Su}$. & - & 13.2 & 5.81 & - & $370-520$ & 1 \\
\hline & A. & 11.15 & 11.2 & 4.40 & $310-390$ & - & 1 \\
\hline \multicolumn{8}{|l|}{ Diaphus vanhoeffeni } \\
\hline Brauer, 1906 & A. & - & 19.8 & 4.51 & - & $45-107$ & 1 \\
\hline Hygophum benoiti & Sp. & 13.50 & 13.5 & $2.46-3.39$ & $360-470$ & $50-100,520-1130$ & 3 \\
\hline \multirow[t]{3}{*}{ (Cocco, 1838) } & Su. & - & 18.3 & 4.02 & - & $0-55$ & 1 \\
\hline & A. & $9.85-10.25$ & 19.3 & $1.50-2.68$ & $460-870$ & $0-105,200-325,425-855$ & 512 \\
\hline & W. & 10.30 & 10.3 & 1.51 & $490-1005$ & - & 1 \\
\hline Hygophum reinhardti & Sp. & $10.35-10.50$ & 19.9 & $1.30-2.22$ & $475-1000$ & $100-205$ & 9 \\
\hline \multirow[t]{3}{*}{ (Lütken, 1892) } & $\mathrm{Su}$. & - & 20.1 & $1.82-3.83$ & - & $0-50,98-200$ & 5 \\
\hline & A. & $9.85-11.75$ & 23.0 & $1.60-2.30$ & $490-1005$ & $30-92$ & 8 \\
\hline & W. & - & 18.6 & $2.70-3.36$ & - & $80-190$ & 2 \\
\hline Lampanyctus alatus & Su. & 4.45 & 20.7 & $2.89-8.36$ & $490-995$ & - & 5 \\
\hline Goode \& Bean, 1896 & A. & - & 18.7 & 5.00 & - & $110-195$ & 1 \\
\hline Lampadena speculigera & Sp. & 6.70 & 6.7 & 6.73 & $480-1005$ & - & 1 \\
\hline \multirow[t]{2}{*}{ Goode \& Bean, 1896} & $\mathrm{Su}$. & - & 15.0 & $2.29-3.25$ & - & $50-98,280-440$ & 4 \\
\hline & A. & $9.35-9.80$ & 11.3 & $3.70-7.00$ & $505-1010$ & - & 3 \\
\hline Lepidophanes guentheri & Sp. & - & 18.2 & $5.69-6.64$ & - & $110-205$ & 2 \\
\hline \multirow[t]{3}{*}{ (Goode \& Bean, 1896) } & Su. & - & 21.7 & $1.77-5.85$ & - & $0-100$ & 6 \\
\hline & A. & 9.80 & 16.8 & 3.20 & $505-1010$ & $110-200$ & 1 \\
\hline & W. & - & 15.3 & 5.58 & - & $40-100$ & 1 \\
\hline Lampanyctus nobilis & Su. & - & 21.7 & $1.22-1.93$ & - & $0-50$ & 5 \\
\hline Tảning, 1928 & W. & - & 19.2 & $1.60-5.74$ & - & $40-190$ & 53 \\
\hline \multicolumn{8}{|l|}{ Lampanyctus tenuiformis } \\
\hline Brauer, 1906 & Su. & - & 16.3 & 7.61 & - & - & 1 \\
\hline \multicolumn{8}{|l|}{ Lampanyctus macropterus } \\
\hline Brauer, 1904 & $\mathrm{Su}$. & - & 16.9 & 2.92 & - & $45-100$ & 1 \\
\hline \multicolumn{8}{|l|}{ Bolinichthys supralateralis } \\
\hline (Parr, 1968) & W. & - & 15.3 & 1.95 & - & - & 1 \\
\hline Loweina interrupta & Sp. & - & 15.5 & 2.97 & - & $45-95$ & 1 \\
\hline \multirow{2}{*}{ (Tåning, 1928) } & Su. & 9.45 & 15.4 & $2.41-7.01$ & $300-398$ & $52-105$ & 10 \\
\hline & A. & 10.25 & 10.3 & 2.57 & $460-870$ & - & 1 \\
\hline \multicolumn{8}{|l|}{ Myctophum selenops } \\
\hline Tåning, 1928 & Sp. & - & 18.2 & $1.71-1.72$ & - & $110-205$ & 2 \\
\hline Notoscopelus caudispinosus & Sp. & - & 19.5 & $2.50-6.10$ & - & $40-205$ & 4 \\
\hline (Johnson, 1863) & Su. & - & 19.0 & $2.60-2.75$ & - & $0-50$ & 2 \\
\hline \multicolumn{8}{|l|}{ Notoscopelus elongatus } \\
\hline (Costa, 1844) & Su. & - & 19.9 & $2.45-13.21$ & - & - & 42 \\
\hline \multicolumn{8}{|l|}{ Symbolophorus rufinus } \\
\hline (Tåning, 1928) & A. & - & 14.7 & 2.63 & - & - & 1 \\
\hline Taaningichthys bathyphilus & $\mathrm{Su}$. & - & 9.3 & 3.24 & - & - & 1 \\
\hline (Tåning, 1928) & A. & 9.70 & 9.7 & 4.60 & $500-995$ & - & 1 \\
\hline Taaningichthys minimus & Su. & - & 16.8 & 3.94 & - & $200-305$ & 1 \\
\hline (Tåning, 1928) & A. & 9.80 & 9.8 & 1.80 & $505-1010$ & - & 1 \\
\hline
\end{tabular}



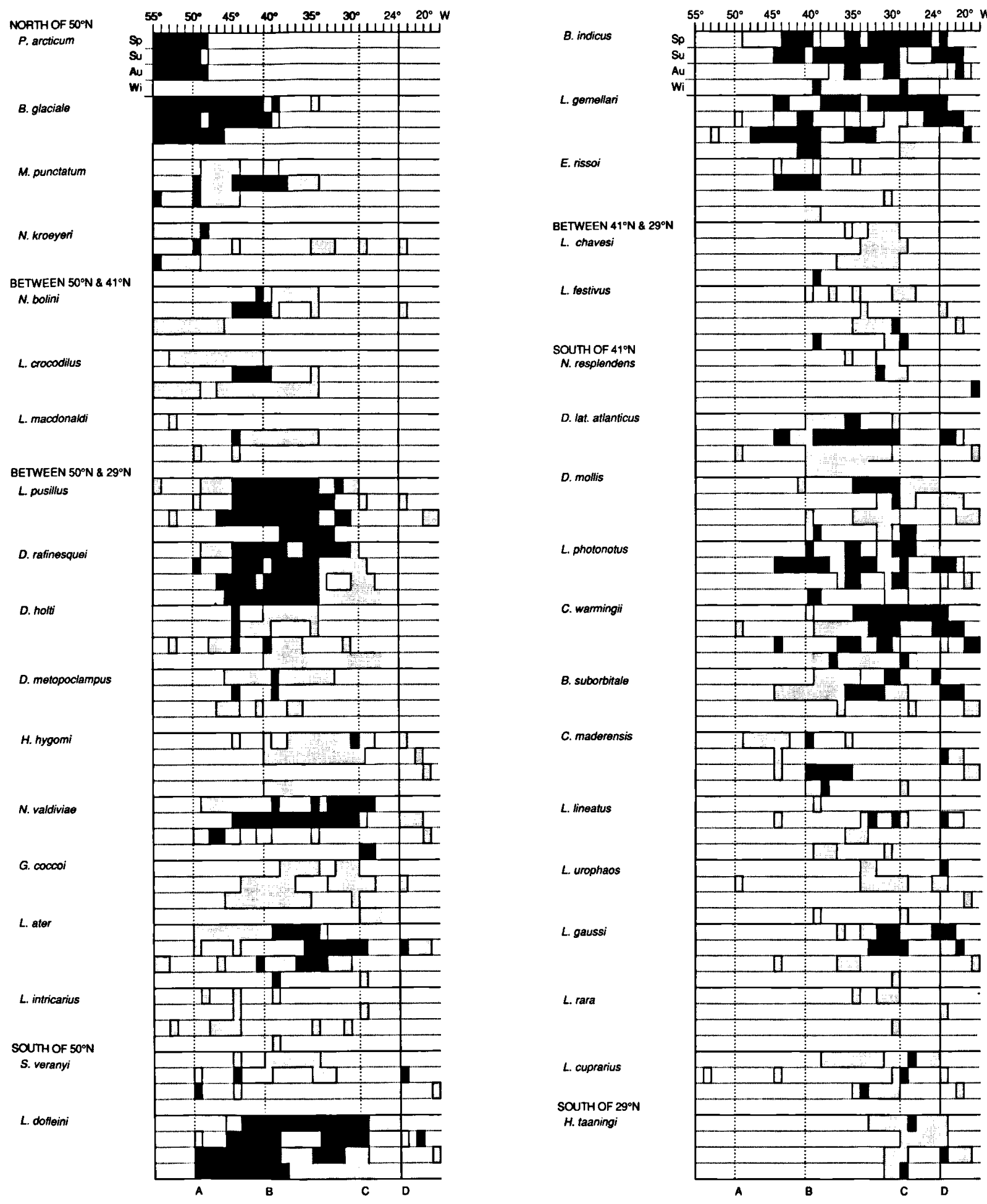

Fig. 1. North-south ranges of myctophids between $24^{\circ} \mathrm{N}$ and $55^{\circ} \mathrm{N}$ along approx. $30^{\circ} \mathrm{W}$ left of line $\mathrm{D}$, and between $20^{\circ} \mathrm{W}$ and $30^{\circ} \mathrm{W}$ along approx. $25^{\circ} \mathrm{N}$ right of line $\mathrm{D}$. For each species the ranges for spring (Sp), summer (Su) autumn (A) and winter (W) are given below each other. The lines A, B, and C mark the latitudes considered to separate the groups distinguished in Table I. Dark is abundant, dotted is rare occurrence. 

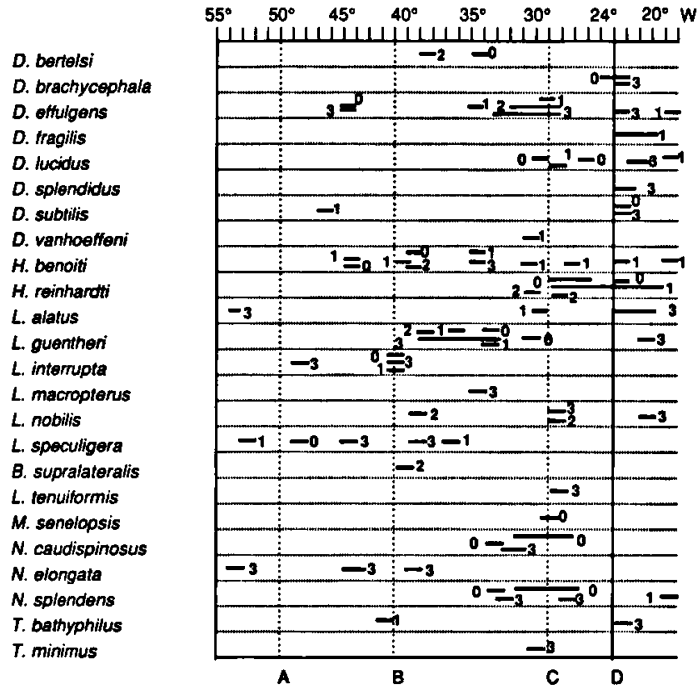

Fig. 2. North-south ranges of incidentally collected myctophids, grouped as in Fig. 1 but the seasons are given together, marked with $0=$ spring, $1=$ autumn, $2=$ winter, and $3=$ summer.

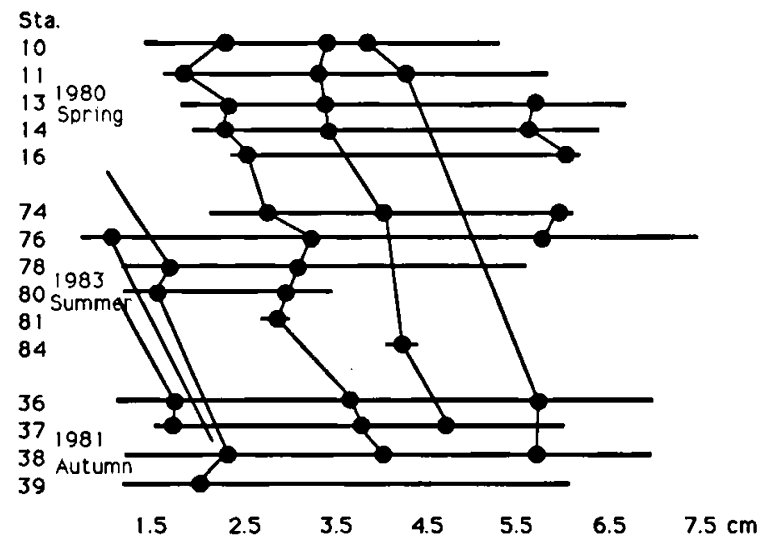

Fig. 3. Size-class maxima per station for spring (1980), summer (1983), and autumn (1981) showing the relation between local and time differences in size of Benthosema glaciale.

southwards to $35^{\circ} \mathrm{N}$ the average size of the specimens increases, though even at $55^{\circ} \mathrm{N}$ no small sizeclass representatives are collected. In summer the population withdraws to $41^{\circ} \mathrm{N}$ and an extra sizeclass, probably due to earlier reproduction (Halliday, 1970), is found in the population between $50^{\circ} \mathrm{N}$ and $41^{\circ} \mathrm{N}$ (Fig. 3). The largest specimens of this size-class are found in the southern stations (78, $80)$, so that a transport from a northern breeding ground (Fig. 3 ) is supposed. In autumn the popula-
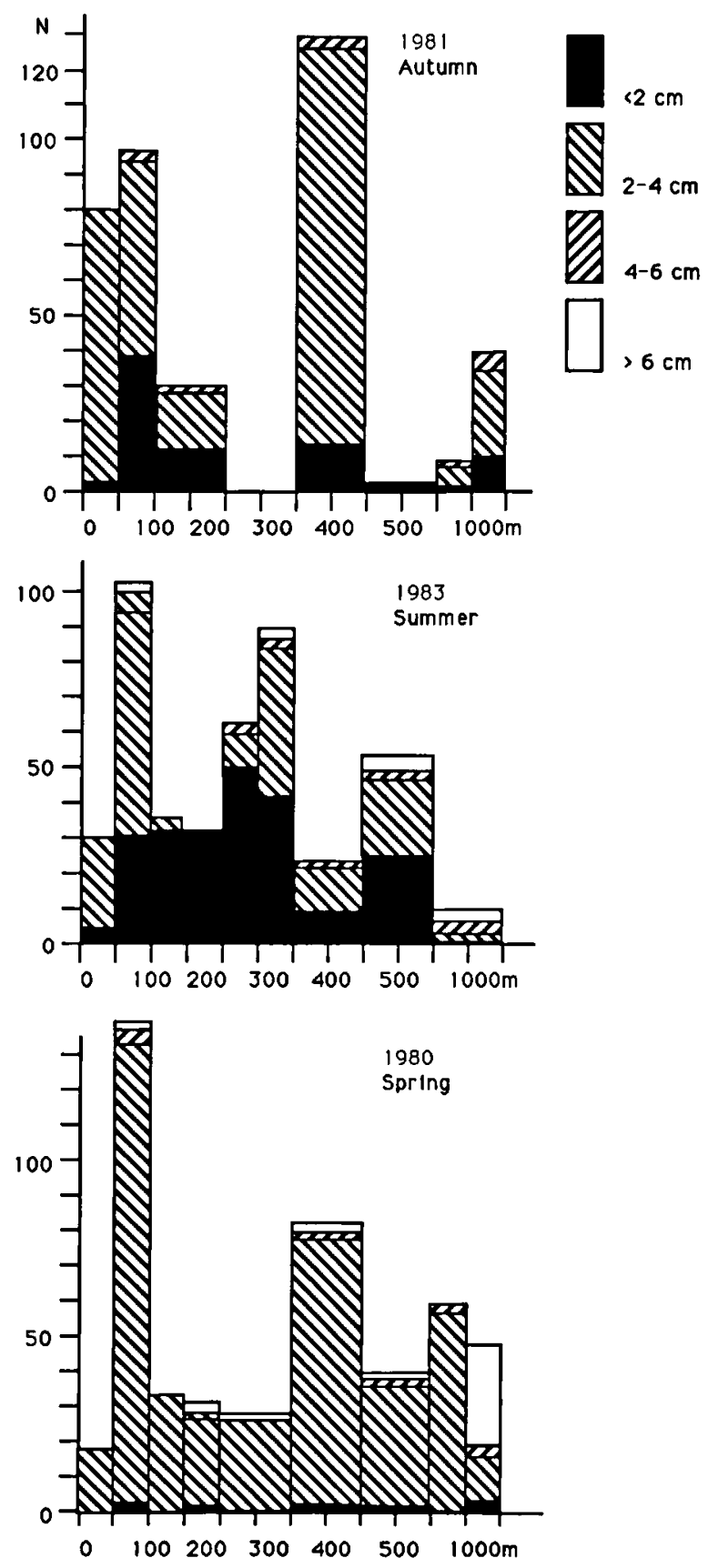

Fig. 4. Depth distribution of four size-groups of Benthosema glaciale in spring (1980), summer (1983), and autumn (1981); number of specimens along horizontal, depth along vertical axis.

tion occurs only north of $47^{\circ} \mathrm{N}$. The penetration to $35^{\circ} \mathrm{N}$ occurs in spring, followed by a regression towards the north later in the year. 
Table II. Size ranges $(\mathrm{cm})$ for Benthosema glaciale in the upper $100 \mathrm{~m}$; stations arranged from north to south.

\begin{tabular}{|c|c|c|c|c|c|}
\hline \multicolumn{2}{|c|}{ Spring (1980) } & \multicolumn{2}{|c|}{ Summer (1983) } & \multicolumn{2}{|c|}{ Autumn (1981) } \\
\hline Sta. & size range & Sta. & size range & Sta. & size range \\
\hline 11 & $2.0-2.7$ & 74 & $2.2-6.0$ & 36 & $1.2-3.9$ \\
\hline 13 & $1.9-6.6$ & & & 37 & $1.6-5.4$ \\
\hline 14 & $2.0-6.0$ & 78 & $1.2-4.8$ & 39 & $1.3-2.3$ \\
\hline 16 & $2.6-3.1$ & 80 & $1.2-3.2$ & & \\
\hline 17 & $2.4-3.6$ & & & & \\
\hline 20 & $2.4-2.8$ & & & & \\
\hline
\end{tabular}

A clear trend in vertical size distribution is found. The highest concentration of smaller specimens $(<$ $20 \mathrm{~mm}$ ), expressed as averages of percentual occurrence per depth level at each station, occurs between $50 \mathrm{~m}$ and $300 \mathrm{~m}$ (Fig. 4) in summer as well as in autumn. The largest specimens $(>60 \mathrm{~mm}$ ) are mostly deeper living. In analogy with the migration of pteropods and medusae (Pafort - Van Iersel, 1985) it can be supposed that the population of the present species, together with its juveniles, is transported southwards in the area between $55^{\circ} \mathrm{N}$ and $35^{\circ} \mathrm{N}$ in the submerging (sub)polar wates. If, however, the upper $100 \mathrm{~m}$ of the water column is studied separately (Table II) the northern stations yield larger specimens than the southern stations. An overall northward migration seems to prevail in the upper $100 \mathrm{~m}$, which may also explain a summer withdrawal from the area between $47^{\circ} \mathrm{N}$ and $35^{\circ} \mathrm{N}$. Diurnal vertical migration in $B$. glaciale is found in spring, summer, and autumn. In spring, the day and night levels overlap, but in the other seasons separation of these levels is evident (Fig. 5).

Benthosema suborbitale is an eurytropical species occurring south of $41^{\circ} \mathrm{N}$, migrating northwards in summer (Fig. 1).

Bolinichthys indicus. No distinct size-classes could be separated, though specimens of 12-20 $\mathrm{mm}$ form a small size-class in spring. A group of specimens ranging from $20-40 \mathrm{~mm}$ shows three maxima, one below and two above the minimum size of maturity $(31 \mathrm{~mm})$. In summer, the majority reaches mature size and the group of small ones decreases in numbers. In autumn, a number of small specimens $(13-26 \mathrm{~mm})$ seems to originate

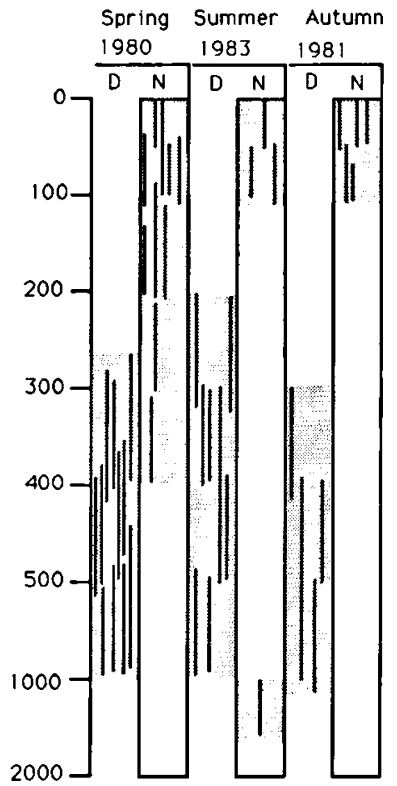

Fig. 5. Vertical migration of Benthosema glaciale in spring (1980), summer (1983), and autumn (1981) in the upper $2000 \mathrm{~m}$; $\mathrm{D}=$ day, $\mathrm{N}=$ night.

from recent hatching. Reproduction throughout the year, with a maximum in early summer, may explain these size distributions.

Bolinichthys supralateralis. The single specimen in the present material is collected at $39^{\circ} 43^{\prime} \mathrm{N}$ $35^{\circ} 48.9^{\prime} \mathrm{W}, 100-200 \mathrm{~m}$ depth, on 15 February 1982. It constitutes a very northern record for this side of the North Atlantic Ocean.

Ceratoscopelus maderensis. In spring and summer only large specimens ( $>40 \mathrm{~mm}$ ) are found in the area influenced by the branches of the North Atlantic Drift (Fig. 6). Small specimens ( $<40 \mathrm{~mm}$ ) are collected in summer, autumn, and winter along the whole transect south of $45^{\circ} \mathrm{N}$. This is reverse of what is found for $C$. warmingii; the two species seem to be vicariating when the large individuals are considered. This is also in agreement with the statement that $C$. maderensis breeds in the northern part of the Gulf Stream (Gibbs et al., 1971) as a temperate species (Backus \& Craddock, 1977), in contrast to the tropical-subtropical $C$. warmingii.

Ceratoscopelus warmingii. There are two sizeclasses throughout the year except in winter. The size-class maxima are in spring 20 and $42 \mathrm{~mm}$, in summer 22 and $43 \mathrm{~mm}$, in autumn 20 and $42 \mathrm{~mm}$, 


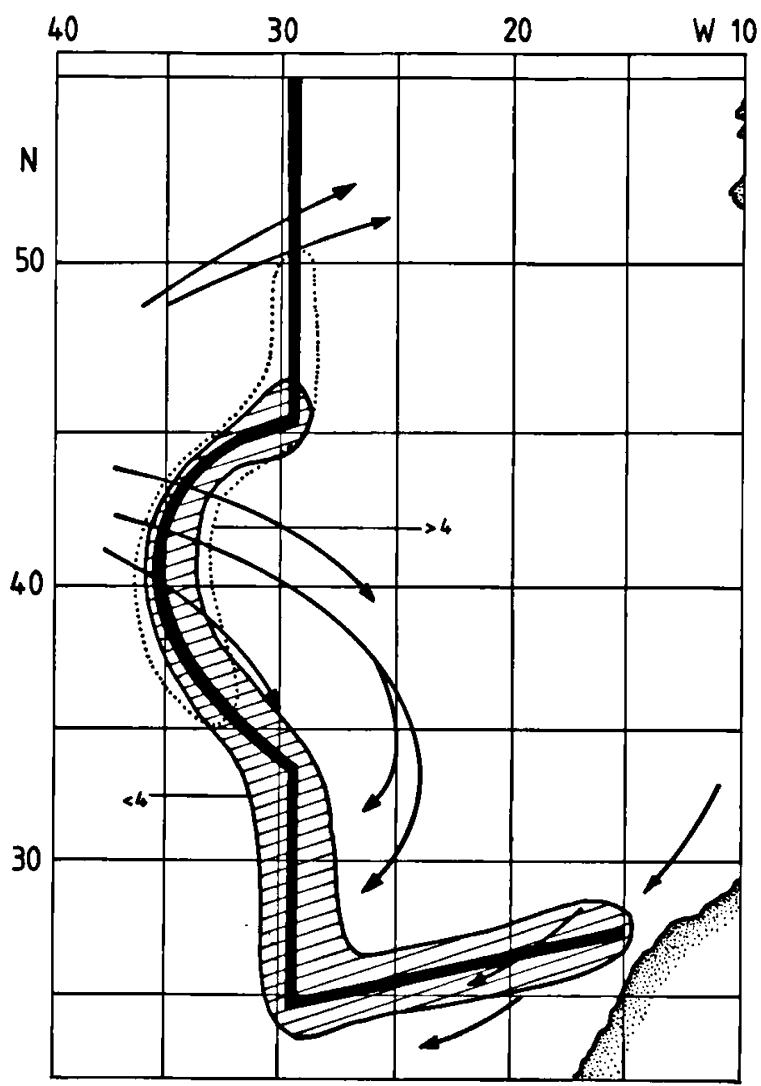

Fig. 6. Geographic pattern of Ceratoscopelus maderensis: large specimens $(>4 \mathrm{~cm})$ in dotted frame and small specimens $(<4$ $\mathrm{cm}$ ) hatched, showing the larger ones in the North Atlantic Drift area.

and in winter $24 \mathrm{~mm}$. In winter the larger size-class disappears from the area investigated. The minimum sizes are for spring $11 \mathrm{~mm}$, for summer 11 $\mathrm{mm}$, for autumn $16 \mathrm{~mm}$, and for winter $17 \mathrm{~mm}$. The larger size-class is most abundant in spring and decreases subsequently. In summer and spring small specimens are found only in the area influenced by the Canary Current. In autumn and winter small ones are also found more to the north in waters influenced by the North Atlantic Drift. The specimens of the larger size-class are restricted mainly to the area south of $40^{\circ} \mathrm{N}$ in all seasons (Fig. 7). In winter, $C$. warmingii is probably restricted to European waters over the continental slope to disperse in spring to oceanic waters south of $40^{\circ} \mathrm{N}$.

For $C$. warmingii evident differences are found in the diurnal vertical distribution in the different seasons (Fig. 8). The upper night level is found

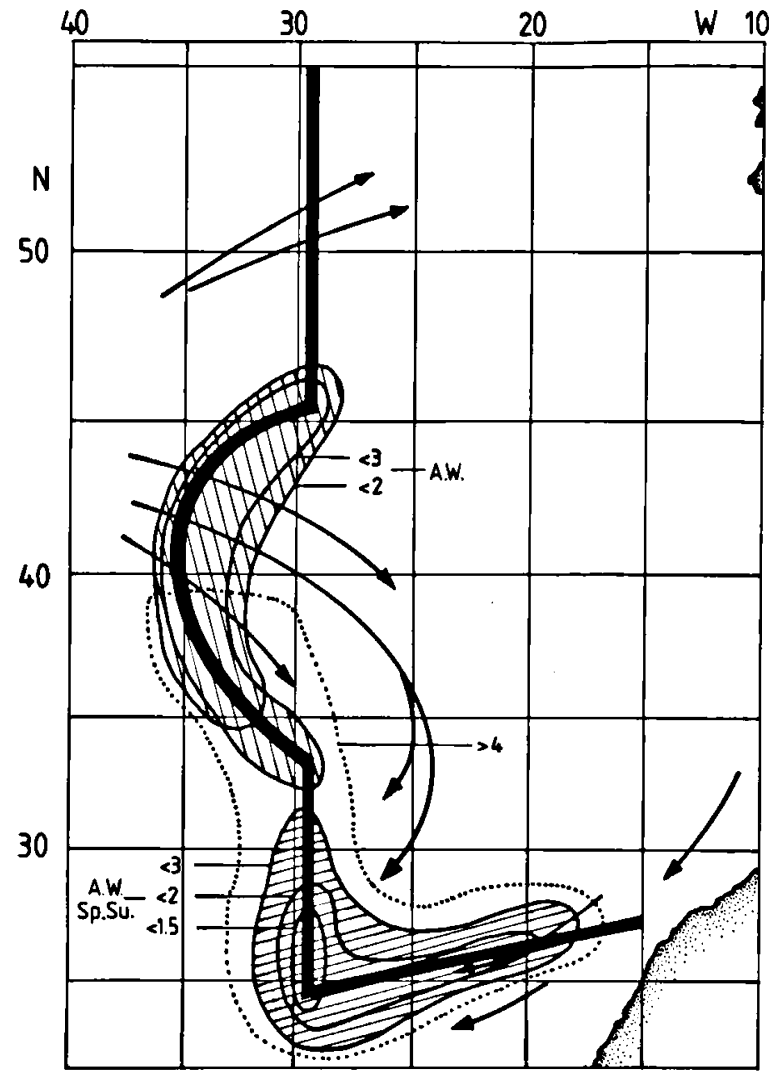

Fig. 7. Geographic pattern of Ceratoscopelus warmingii: large specimens $(>4 \mathrm{~cm})$ in dotted frame, smaller size groups $(<2$ and $<3 \mathrm{~cm}$ ) hatched, collected in autumn and winter (A. W.) and in all seasons (A. W. Sp. Su.).

above $50 \mathrm{~m}$ in summer and autumn and below $50 \mathrm{~m}$ in spring and winter. The (upper) day levels in spring and autumn are identical, reaching the 500-1000 m layers. In summer the species is not collected at daytime as it occurs probably too deep; in winter the day level is found between 100 and $300 \mathrm{~m}$.

Diaphus lucidus is only collected south of $30^{\circ} \mathrm{N}$ though it may occur more northward (Hulley, 1984).

Diaphus metopoclampus is not found in the winter samples. In spring there are two size groups (12-25 $\mathrm{mm}$ and 53-70 $\mathrm{mm}$ ). In summer these groups are still present $(20-36 \mathrm{~mm}$ and 58-71 $\mathrm{mm})$. In autumn one specimen of $20 \mathrm{~mm}$ and a group of $31-50 \mathrm{~mm}$ is found.

Diaphus mollis. In spring large (> $30 \mathrm{~mm}$ ), and in autumn small $(<30 \mathrm{~mm})$ specimens are 


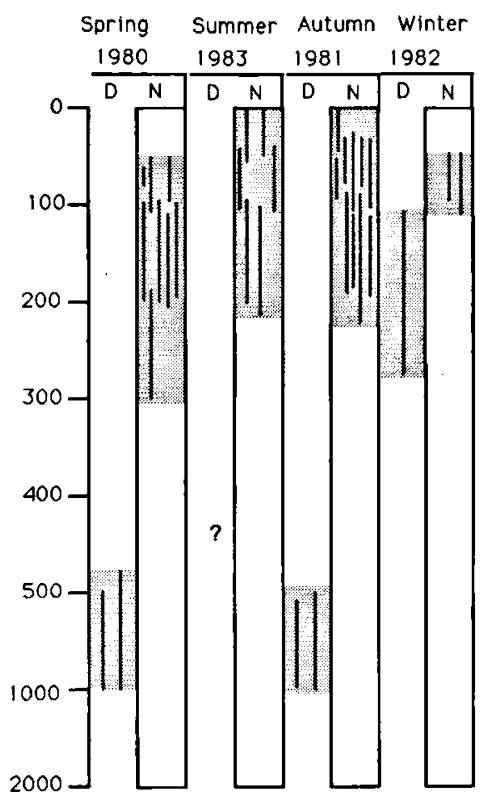

Fig. 8. Vertical migration of Ceratoscopelus warmingii in spring (1980), summer (1983), autumn (1981), and winter (1982).

dominating. No small specimens were collected winter.

Diaphus rafinesquei is mature at a standard length of $50 \mathrm{~mm}$. It breeds in the eastern Atlantic and transport by currents brings the specimens in the western Atlantic (Nafpaktitis, 1968).

Size-classes are found around maxima of $21 \mathrm{~mm}$, $34 \mathrm{~mm}, 57 \mathrm{~mm}$, and $70 \mathrm{~mm}$ in spring, $20 \mathrm{~mm}, 38$ $\mathrm{mm}$, and $60 \mathrm{~mm}$ in summer, $47 \mathrm{~mm}$ and $66 \mathrm{~mm}$ in autumn, and $20 \mathrm{~mm}, 55 \mathrm{~mm}$, and $65 \mathrm{~mm}$ in winter. The maximum length of specimens in the present collection is $86 \mathrm{~mm}$. In autumn nearly no small specimens are found. In winter a new size-class occurs and this group can also contribute to the higher numbers of small specimens in spring and summer. The small specimens in spring were concentrated around the stations 16,17 , and 18 in the North Atlantic Drift. Size-classes are indicated by 'A' to ' $J$ ' in Fig. 9; it is supposed that the size-classes up to ' $D$ ' consist of juveniles and those from ' $E$ ' to ' $J$ ' of adults, in which the group ' $\mathrm{J}$ ' can be considered as probably representing large expatriated specimens. Due to inefficient preservation a study of otoliths was impossible.

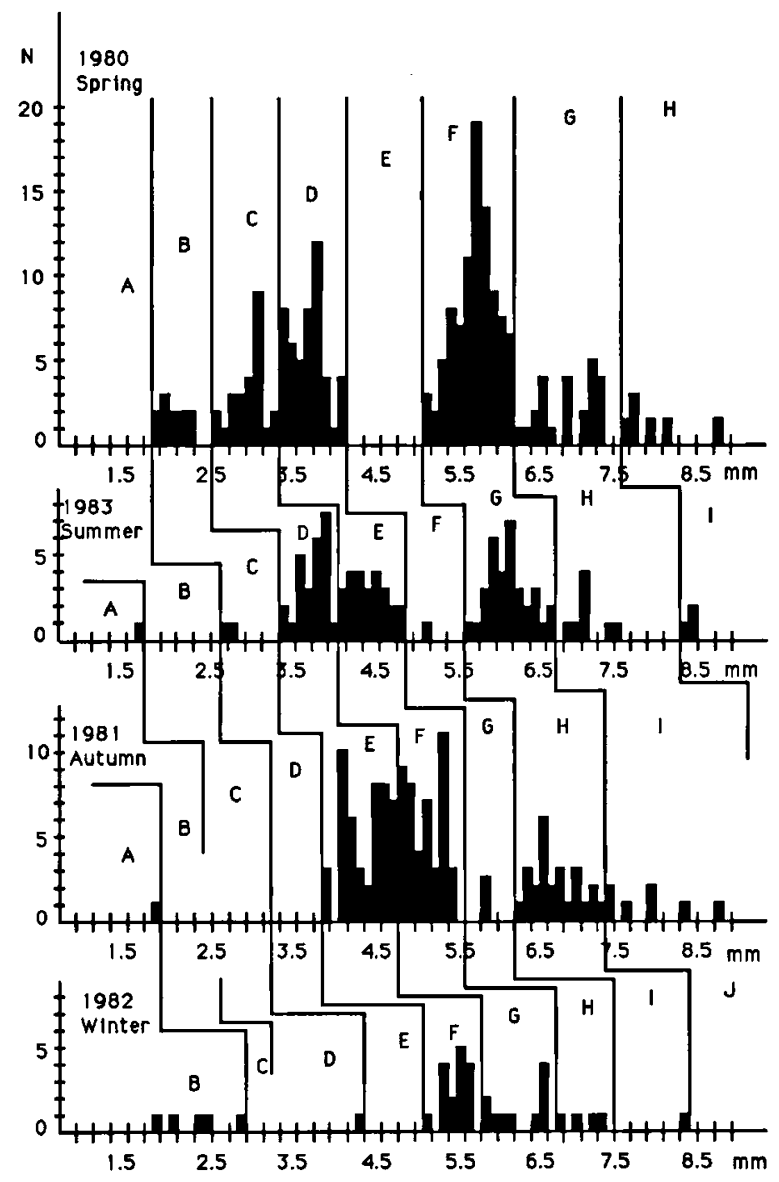

Fig. 9. Histogram of size (standard length) distribution for Diaphus rafinesquei: for spring (1980), summer (1983), autumn (1981), and winter (1982). Numbers of specimens along vertical, standard length along horizontal axis. The size-classes are indicated with $\mathrm{A}-\mathrm{J}$ for each season so that class $\mathrm{A}$ in spring becomes $B$ in summer and $C$ in autumn, etc.

The size-classes plotted in Fig. 10 along the cruise transect show their relative position with regard to the North Atlantic Drift. The southern branch of the North Atlantic Drift is populated by small and large specimens; further remote from this water mass only larger ones are found. The temperature/salinity (T/S) ratios of the actual, positive sampling localities were plotted in Fig. 11 with the $\mathrm{T} / \mathrm{S}$ ratio for the North Atlantic Drift in the upper $50 \mathrm{~m}$ of the water column for 1981 and 1983, the only two years for which accurate $T$ and $S$ data are available (Van der Spoel, 1985). From this figure it is evident that there is a relation of small specimens 


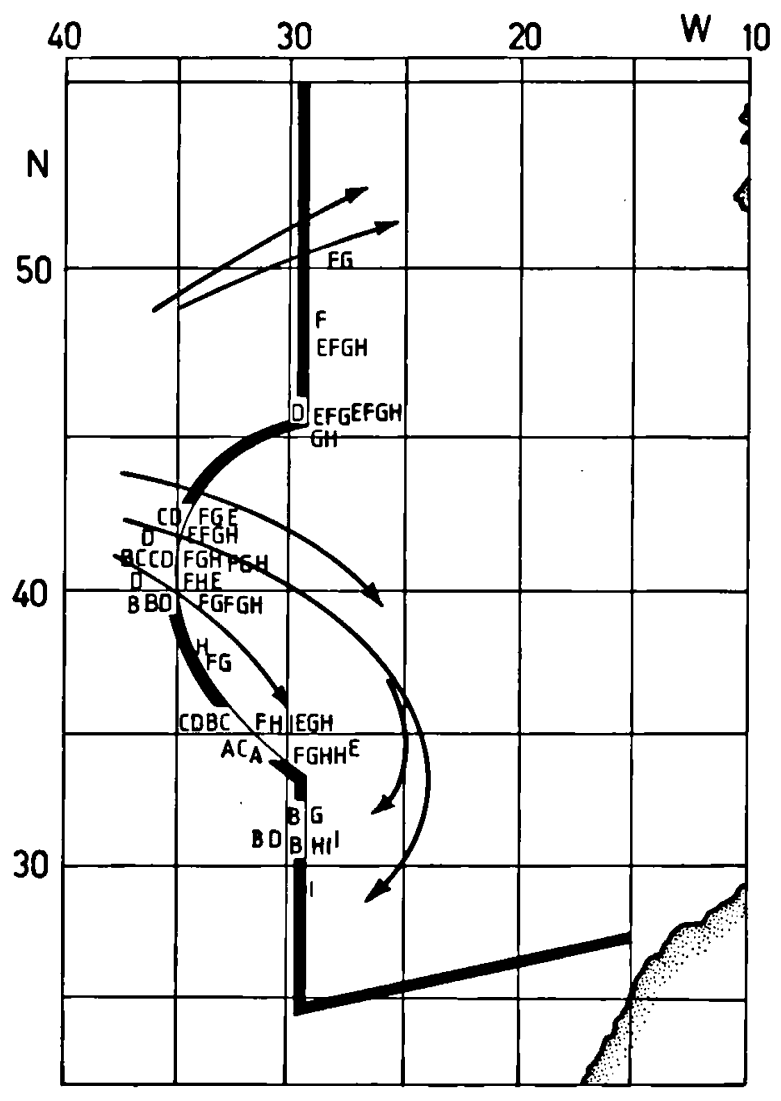

Fig. 10. Geographic distribution of the size-classes $\mathrm{A}-\mathrm{J}$ from Fig. 9 along the cruise transect.

with the North Atlantic Drift expressed in $\mathrm{T} / \mathrm{S}$ values. In summer, when there are many small specimens $(<4 \mathrm{~mm})$, these are found in water masses in T/S close to the North Atlantic Drift. In autumn the few small ones are already further away from the current than in summer, and in summer and autumn the full-grown are found in water masses which differ in $T / S$ ratios more from the North Atlantic Drift than the water masses in which the small specimens are found (Fig. 11).

It is concluded on the basis of geographic evidence and water mass characters that the smaller size-classes are transported by the North Atlantic Drift and that the aging animals migrate from this area north and southwards, so that the largest specimens are found at greater distances from the current. This does not exclude of course that a group of adults remains in the current; these may produce the next year's offspring.
Vertical migration shows slight differences in the four seasons. In summer the night and daytime depths are both shallower than in spring. In autumn the spring situation is found again, but in winter both daytime and night depths are greater than in spring (Fig. 12).

The record of Diaphus subtilis at $47^{\circ} 46.5^{\prime} \mathrm{N}$ $30^{\circ} 25.8^{\prime} \mathrm{W}$ on 5 October 1981 at $310-390 \mathrm{~m}$ is the northernmost record of this species, of which hitherto isolated records up to $40^{\circ} \mathrm{N}$ were known for this area (Hulley, 1984).

Hygophum benoiti. All specimens are found in Sargasso Sea water or in waters influenced by the North Atlantic Drift.

Lampanyctus ater is most abundant between $28^{\circ} \mathrm{N}$ and $42^{\circ} \mathrm{N}$. In spring small specimens (11-40 $\mathrm{mm})$ are the most abundant. In winter only small specimens are found $(8-30 \mathrm{~mm})$ and in autumn no small ones are found at all.

Lampanyctus crocodilus. All small specimens are found in the vicinity of the North Atlantic Drift. No small specimens are found in spring. The larger specimens found in spring and autumn probably migrate northwards to the latitudes of $49^{\circ} \mathrm{N}$ to $53^{\circ} \mathrm{N}$ (cf. Fig. 1).

Lampanyctus photonotus shows in all seasons, except for spring, a dominance of small specimens ( $<30 \mathrm{~mm}$ ). In spring the size-class with a maximum of $40 \mathrm{~mm}$ dominates. In summer this maximum is found around $50 \mathrm{~mm}$; in autumn and winter this group of specimens has disappeared. Geographic separation of size-classes is not found.

Lampanyctus pusillus shows two size-classes in spring: a small size-class and a more abundant large size-class. In summer the small size-class becomes more abundant, probably due to early spring reproduction (Hulley, 1984). In winter the catch is small and no small specimens are present.

Lepidophanes gaussi. Though material is limited in spring and autumn, a clear maximum of small specimens $(<20 \mathrm{~mm})$ is collected.

Lobianchia dofleini. This widespread species shows four size-classes in spring (10-18, 19-26, 27-29, and 30-35 $\mathrm{mm}$ ).

Lobianchia gemellari. The previous species was collected more frequently than the present subtropical species; in all seasons juveniles are found. The 


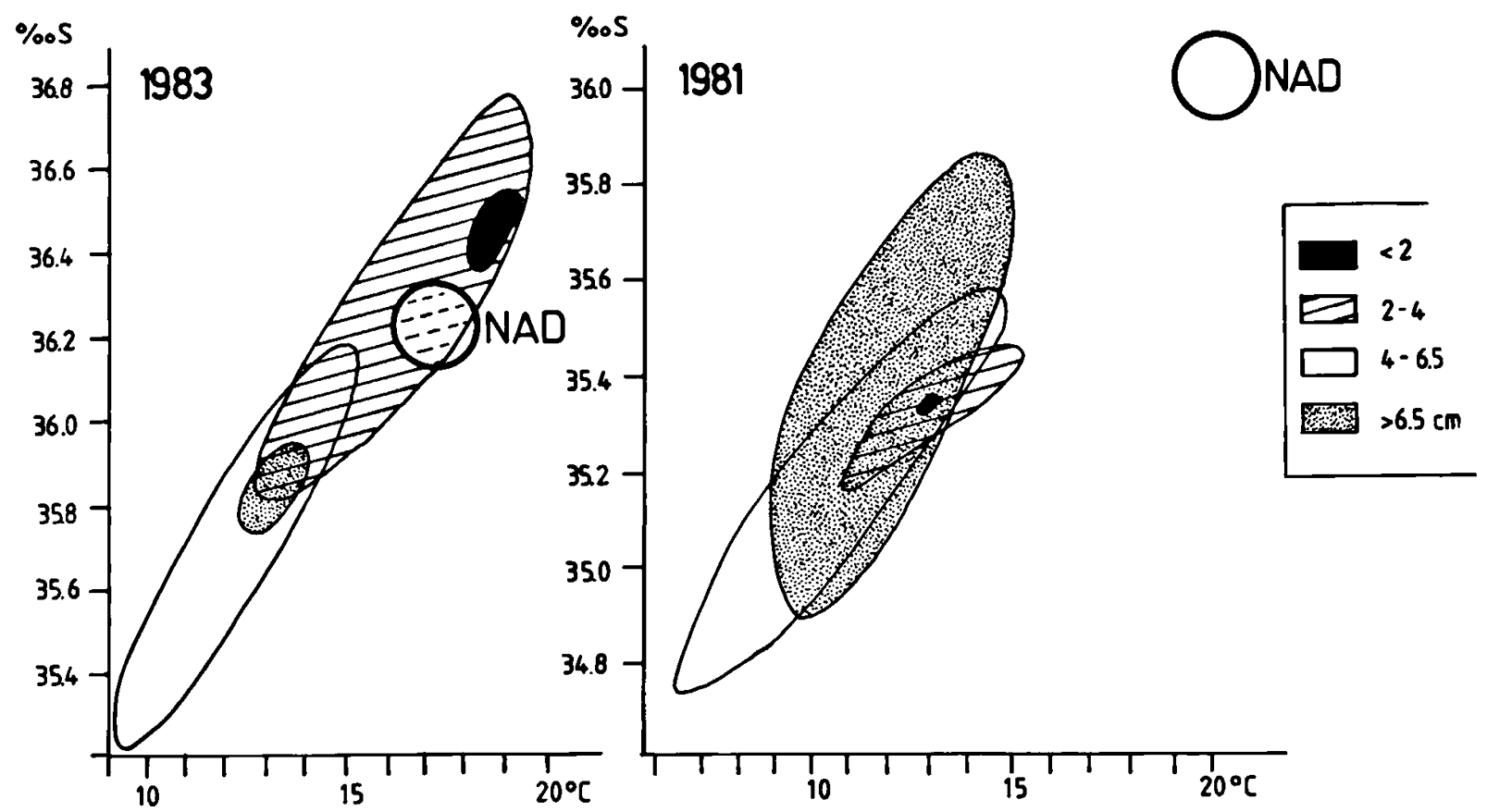

Fig. 11. The temperature/salinity (TS) relations of the positive hauls for Diaphus rafinesquei in summer (1983) and autumn (1981), showing the position of the different size-classes $(<2,2-4,4-6$, and $>6 \mathrm{~cm})$ in relation to the T/S values of the North Atlantic Drift (NAD).

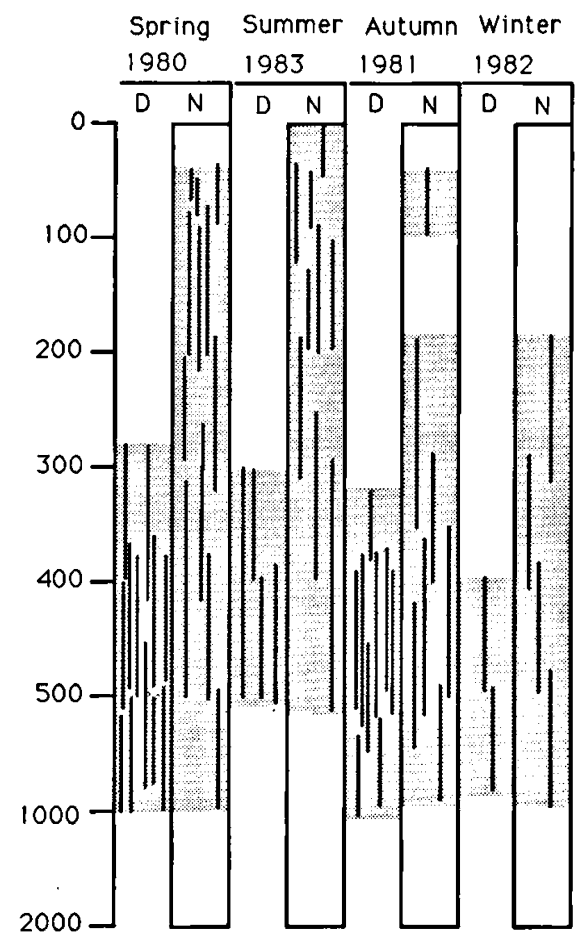

Fig. 12. Vertical migration of Diaphus rafinesquei during spring (1980), summer (1983), autumn (1981), and winter (1982). large specimens $(>80 \mathrm{~mm}$ ) are no expatriates as they are collected in the normal range of the species (cf. Hulley, 1984).

Myctophum punctatum. The large specimens ( $>$ $50 \mathrm{~mm}$ ) are found only at the northernmost positions (spring $49^{\circ} \mathrm{N}$, summer $51^{\circ} \mathrm{N}$, autumn $55^{\circ} \mathrm{N}$ ). Reproduction seems to start in the north in spring (specimens of $\pm 20 \mathrm{~mm}$ ) and to shift towards the south with the seasons, as in summer smaller juveniles $( \pm 20 \mathrm{~mm})$ are found at more southern localities than larger juveniles $( \pm 30 \mathrm{~mm})$. The northsouth range (Fig. 1) also shows an extension to the south in summer.

Notolychnus valdiviae. The mean size increases from $16.5 \mathrm{~mm}$ in spring, $17.4 \mathrm{~mm}$ in summer, 19.0 $\mathrm{mm}$ in autumn, to $18.1 \mathrm{~mm}$ in winter.

\section{Discussion}

To determine the different faunas in the areas investigated, the species can be grouped according to: (1) the occurrence over the provinces proposed by 
Table III. Sum of first and last occurrences of myctophids for each station. The winter cruise is not considered as too few samples were available. The geographic position of the maxima and the position of the faunal borders proposed by Backus \& Craddock (1977) are added.

\begin{tabular}{|c|c|c|c|c|c|c|}
\hline \multicolumn{2}{|c|}{ Spring (1980) } & \multicolumn{2}{|c|}{ Summer (1983) } & \multicolumn{2}{|c|}{ Autumn (1981) } & \multirow{2}{*}{$\begin{array}{l}\text { Borders after } \\
\text { Backus \& Craddock }\end{array}$} \\
\hline Sta. & $\Sigma$ & Sta. & $\Sigma$ & Sta. & $\Sigma$ & \\
\hline 10 & 4 & 74 & 6 & 36 & 10 & . \\
\hline 11 & 3 & 75 & 0 & 37 & 4 & . \\
\hline 13 & $11\left(48^{\circ}\right)$ & 76 & $12\left(50^{\circ}\right)$ & 38 & $8\left(49^{\circ}\right)$ & $51^{\circ} \mathrm{N}$ \\
\hline 14 & 10 & 77 & 0 & 39 & 8 & . \\
\hline 16 & 3 & 78 & $18\left(45^{\circ}\right)$ & 40 & 6 & . \\
\hline 17 & 6 & 80 & 2 & 42 & 3 & . \\
\hline 18 & 8 & 81 & 6 & 43 & 6 & . \\
\hline 19 & 2 & 84 & $14\left(35^{\circ}\right)$ & 45 & $12\left(37^{\circ}\right)$ & $36^{\circ} \mathrm{N}$ \\
\hline 20 & $12\left(35^{\circ}\right)$ & 85 & 11 & 47 & 4 & . \\
\hline 21 & 3 & 87 & 5 & 48 & 2 & . \\
\hline 22 & 3 & 987 & 5 & 49 & 7 & . \\
\hline 23 & 1 & 88 & 0 & 50 & $9\left(30^{\circ}\right)$ & $30^{\circ} \mathrm{N}$ \\
\hline 24 & $11\left(29^{\circ}\right)$ & 89 & $25\left(25^{\circ}\right)$ & 51 & 1 & . \\
\hline 25 & 4 & 90 & 18 & 52 & 1 & . \\
\hline 26 & 3 & & & 53 & 2 & . \\
\hline \multirow[t]{2}{*}{27} & 16 & & & 54 & 4 & . \\
\hline & & & & 55 & 21 & . \\
\hline
\end{tabular}

Backus \& Craddock (1977), (2) the north-south distribution along the transect, (3) the temperature preferences, and (4) the co-occurrences in the samples.

The study of first and last occurrences, a method only giving an indication for faunal borders, may also be mentioned. This mathematical method for estimating faunal borders proposed by Backus et al. (1965) is not followed as the model assumes homogeneous dispersal which is certainly not the case. The simple sum of first- and last-occurrences for all stations is given in Table III. There is a slight resemblance between the faunal borders proposed by Backus \& Craddock (1977) and the first and last occurrences in the present material.

Difficulties with the methods mentioned above induced us to propose a mathematical approach (also published by Bleeker \& Van der Spoel, 1988) to measure the collected material of each station departing from the following assumptions:

A species has no value for a sample when it does not contribute to the diversity of the sample and when it does not determine the character of the sample by a certain dominance. The importance of a species for a sample is thus greater when its diversity value $(D)$ and its dominance value $(C)$ are higher. The difference of these values from zero is the loading of the species $(B)$ (for full discussion of the formulas see Bleeker \& Van der Spoel, 1988) which is expressed in the formulas:

$$
B=\sqrt{D^{2}+C^{2}}
$$

and

$$
C=\frac{100 \times F \cdot N-\Sigma N}{F \times N_{\max }-\Sigma N} \times \frac{F}{F_{\max }}
$$

and

$$
D=\sqrt{\left(1+A_{\max }-A\right)^{2} \times(1+M-A) \times N}
$$

in which $A=$ the number of samples in which the species is found, $A_{\max }=$ the number of samples in which the most frequently occurring species is found, $B=$ the species loading, $C=$ value of a species' dominance for the sample, $D=$ diversity value of a species for the sample, $F=$ number of species 
Table IV. $\Sigma B$ for Myctophidae ( $\Sigma B)$, Phronimidae ( $\left.\Sigma B^{\prime}\right)$ and Periphyllidae ( $\left.\Sigma B^{\prime \prime}\right)$ for the spring, summer, and autumn cruise. The geographic positions $\left({ }^{\circ} \mathrm{N}\right)$ of the maxima are added.

\begin{tabular}{|c|c|c|c|c|c|c|c|c|c|}
\hline \multicolumn{4}{|c|}{ Spring (1980) } & \multicolumn{3}{|c|}{ Summer (1983) } & \multicolumn{3}{|c|}{ Autumn (1981) } \\
\hline Sta. & $\Sigma B$ & $\Sigma B^{\prime}$ & $\Sigma B^{\prime \prime}$ & Sta. & $\Sigma B$ & $\Sigma B^{\prime \prime}$ & Sta. & $\Sigma B$ & $\Sigma B^{\prime \prime}$ \\
\hline 10 & $691\left(55^{\circ}\right)$ & - & 10 & 74 & 468 & 209 & 36 & 908 & 135 \\
\hline 11 & 457 & - & 169 & 75 & 174 & 9 & 37 & $1691\left(53^{\circ}\right)$ & 111 \\
\hline 12 & - & 0 & - & 76 & $797\left(50^{\circ}\right)$ & $234\left(50^{\circ}\right)$ & 38 & 1231 & $148\left(50^{\circ}\right)$ \\
\hline 13 & 836 & 54 & 180 & 77 & 0 & - & 39 & 762 & 42 \\
\hline 14 & $841\left(45^{\circ}\right)$ & 80 & 229 & 78 & $1516\left(45^{\circ}\right)$ & 174 & 40 & 632 & - \\
\hline 16 & 319 & 120 & $231\left(41^{\circ}\right)$ & 80 & 875 & - & 42 & 407 & $205\left(41^{\circ}\right)$ \\
\hline 17 & 641 & 383 & 75 & 81 & 645 & 230 & 43 & 345 & 204 \\
\hline 18 & 661 & 429 & 194 & 84 & 661 & $429\left(35^{\circ}\right)$ & 45 & 639 & 94 \\
\hline 19 & 438 & $464\left(38^{\circ}\right)$ & $366\left(38^{\circ}\right)$ & 85 & $1005\left(33^{\circ}\right)$ & - & 47 & $702\left(35^{\circ}\right)$ & $313\left(35^{\circ}\right)$ \\
\hline 20 & $1236\left(35^{\circ}\right)$ & 99 & 343 & 87 & 461 & 80 & 48 & 336 & 141 \\
\hline 21 & 249 & $692\left(33^{\circ}\right)$ & 295 & 987 & 510 & 0 & 49 & 592 & 43 \\
\hline 22 & $811\left(32^{\circ}\right)$ & 74 & 243 & 89 & $1040\left(25^{\circ}\right)$ & $151\left(25^{\circ}\right)$ & 50 & $688\left(30^{\circ}\right)$ & 0 \\
\hline 23 & 0 & 4 & $304\left(31^{\circ}\right)$ & 90 & 431 & - & 51 & 15 & $286\left(28^{\circ}\right)$ \\
\hline 24 & $640\left(29^{\circ}\right)$ & $330\left(29^{\circ}\right)$ & 0 & & & & 52 & 182 & 236 \\
\hline 25 & 483 & 125 & 0 & & & & 53 & 0 & - \\
\hline 26 & 281 & $288\left(25^{\circ}\right)$ & 0 & & & & 54 & 337 & - \\
\hline 27 & 437 & 123 & 0 & & & & 55 & 621 & - \\
\hline
\end{tabular}

found in the sample, $F_{\max }=$ total number of species in the most diverse sample, $M=$ total number of samples, $N=$ total number of specimens in the sample, $N_{\max }=$ total number of specimens in the most abundant sample.

The total of loadings of species $(B)$ in a sample $(\Sigma B)$ is an expression of the diversity and quality of the sample. In Table IV the $\Sigma B$ is given for Myctophidae ( $\Sigma B)$, Phronimidae (Crustacea, Amphipoda) $\left(\Sigma B^{\prime}\right)$ and Periphyllidae (Medusae, Scyphozoa) $\left(\Sigma B^{\prime \prime}\right)$. Table IV shows more transition zones for the spring period than the ones indicated by first and last occurrences (Table III); borders near $29^{\circ} \mathrm{N}, 35^{\circ} \mathrm{N}$, and $45^{\circ} \mathrm{N}$ are evident in both tables, but the loading of the stations shows also transitions near $55^{\circ} \mathrm{N}$ and $32^{\circ} \mathrm{N}$. Near $25^{\circ} \mathrm{N}, 29^{\circ} \mathrm{N}$, $33^{\circ} \mathrm{N}, 38^{\circ} \mathrm{N}$, and $31^{\circ} \mathrm{N}, 38^{\circ} \mathrm{N}, 41^{\circ} \mathrm{N}$, respectively, Phronimidae and Periphyllidae show other transition zones than the Myctophidae. In the summer series the loading of the stations gives transitions for Myctophidae near $50^{\circ} \mathrm{N}, 45^{\circ} \mathrm{N}, 33^{\circ} \mathrm{N}$, and $25^{\circ} \mathrm{N}$, which is rather different from the results in Table III. The Periphyllidae show borders at $50^{\circ} \mathrm{N}$, $35^{\circ} \mathrm{N}$, and $25^{\circ} \mathrm{N}$ in summer. In autumn there is great difference between the results with the load- ings per station and first and last occurrence, but the results of the species loading are much closer to the provinces by Backus \& Craddock (1977). All data together show in spring a transitional zone between $29^{\circ} \mathrm{N}$ and $33^{\circ} \mathrm{N}$, between $35^{\circ} \mathrm{N}$ and $41^{\circ} \mathrm{N}$, and between $45^{\circ} \mathrm{N}$ and $48^{\circ} \mathrm{N}$. In summer these zones are found at $25^{\circ} \mathrm{N}$, between $33^{\circ} \mathrm{N}$ and $35^{\circ} \mathrm{N}$, and at $50^{\circ} \mathrm{N}$, together with a transitional zone near $45^{\circ} \mathrm{N}$. In autumn the transitional zones are found at $28^{\circ} \mathrm{N}-30^{\circ} \mathrm{N}, 35^{\circ} \mathrm{N}-41^{\circ} \mathrm{N}$, and $49^{\circ} \mathrm{N}-53^{\circ} \mathrm{N}$. There is thus a clear shift in transitional areas.

A shift of the borders of the individual species is also obvious; the northern fauna elements migrate southwards in summer and autumn, the temperate elements penetrate northwards and southwards in summer and autumn, and the warm-water elements go northwards in summer. These shifts are also seen in Fig. 1 when the groups as given in Table I are compared. In Table I the species are divided into eight sections. The eighth section comprises species collected incidentally and is not considered any further. The other seven groups are based on the occurrence in relation to the $50^{\circ}, 41^{\circ}$ and $29^{\circ} \mathrm{N}$ borders (lines $\mathrm{A}, \mathrm{B}$, and $\mathrm{C}$ in Fig. 1). The latitudes $50^{\circ} \mathrm{N}$ and $29^{\circ} \mathrm{N}$ are chosen as they represent the 


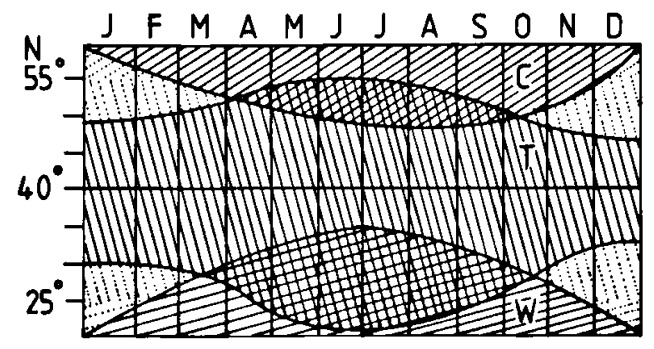

Fig. 13. Diagram of the seasonal shift of cold (C), temperate (T), and warm-water (W) taxa; successive months indicated with $J$ to D.

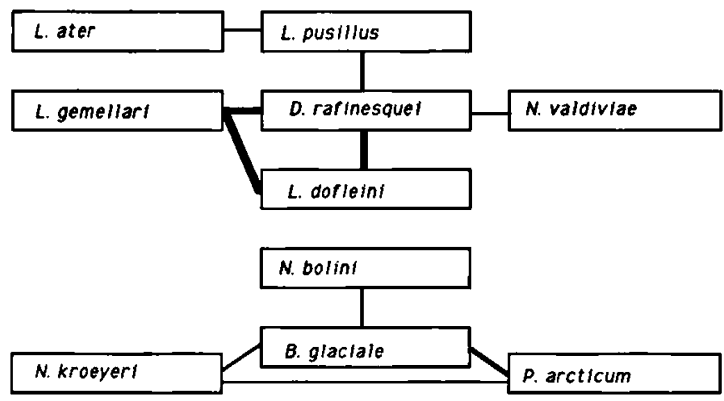

Fig. 14. Co-occurrence model for the autumn samples of the most frequent species based on simultaneous collecting in one net haul. The stronger the co-occurrence, the thicker are the connecting lines.

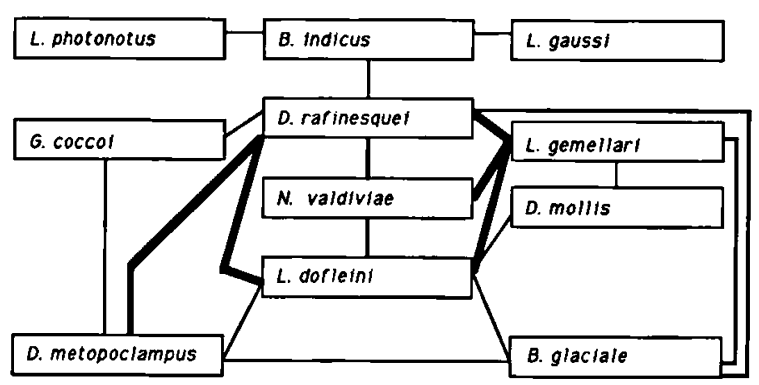

Fig. 15. Co-occurrence model for the spring samples of the most frequent species based on simultaneous collecting in one net haul. The stronger the co-occurrence, the thicker are the connecting lines.

faunal borders also given by Backus \& Craddock (1977) and because they are close to the maxima of first and last occurrences. The border at $36^{\circ} \mathrm{N}$ of Backus \& Craddock (1977) is not considered because it is a transition zone which also delimits extreme southward penetration of northern elements

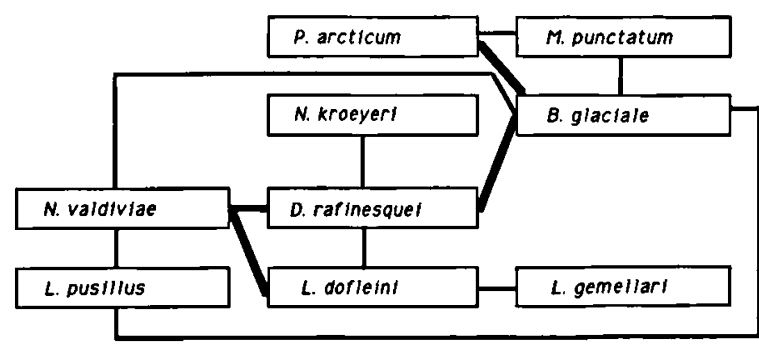

Fig. 16. Co-occurrence model for the summer samples of the most frequent species based on simultaneous collecting in one net haul. The stronger the co-occurrence, the thicker are the connecting lines.

and northward penetration of southern elements (Figs. 1, 13). The provinces given by Backus \& Craddock (1977) could therefore not be used; the faunal elements shift too much during the year to delimit the processes accurately. The border for myctophids at $41^{\circ} \mathrm{N}$ is a hydrographic phenomenon as well. Moreover, this border at $41^{\circ} \mathrm{N}$ is reflected in the zoogeography of other taxonomic groups.

In Fig. 13 the yearly shift of cold- temperate- and warm-water species is diagrammatically illustrated. This shift explains the different results of cooccurrence tests in the different seasons. In autumn cold-water species and temperate species form separate clusters (Fig. 14). B. glaciale, $P$. arcticum, $N$. kroeyeri, and $N$. bolini form a cold-water cluster separated from the warm-water cluster of $D$. rafinesquei, $L$. gemellari, $N$. valdiviae, and $L$. dofleini to which also $L$. ater and $L$. pusillus are linked. In spring there is strong mixing of both clusters probably also induced by new offspring (Fig. 15). A warm-water cluster is recognized in $D$. rafinesquei, $L$. gemellari, $N$. valdiviae, and $L$. dofleini, but strong co-occurrence of these with $\boldsymbol{B}$. glaciale points to mixing of faunas. In summer no separation could be made on the basis of cooccurrence. The cold-water elements $P$. arcticum, $M$. punctatum, B. glaciale, and $N$. kroeyeri are frequently co-occurring with $D$. rafinesquei and $N$. valdiviae from the temperate cluster (Fig. 16).

The temperature ranges at which the species occur do not give an indication of different faunas, neither when day samples or night samples are considered separately, nor when the temperature at 200 $\mathrm{m}$ depth is considered. The temperatures at which 
Table $V$. Temperature ranges of the N-S ranges distinguished in Table I.

\begin{tabular}{lc}
\hline North-south range & $\begin{array}{l}\text { Rounded off temp. of } \\
\text { daytime samples }\end{array}$ \\
\hline north of $50^{\circ} \mathrm{N}$ & $4^{\circ}-14^{\circ} \mathrm{C}$ \\
between $50^{\circ}$ and $41^{\circ} \mathrm{N}$ & $5^{\circ}-10^{\circ} \mathrm{C}$ \\
between $50^{\circ}$ and $29^{\circ} \mathrm{N}$ & $4^{\circ}-15^{\circ} \mathrm{C}$ \\
south of $50^{\circ} \mathrm{N}$ & $5^{\circ}-19^{\circ} \mathrm{C}$ \\
between $41^{\circ}$ and $29^{\circ} \mathrm{N}$ & $10^{\circ}-12^{\circ} \mathrm{C}$ \\
south of $41^{\circ} \mathrm{N}$ & $5^{\circ}-17^{\circ} \mathrm{C}$ \\
south of $29^{\circ} \mathrm{N}$ & $9^{\circ}-10^{\circ} \mathrm{C}$ \\
\hline
\end{tabular}

the species live at daytime still are the most indicative; in Table $\mathrm{V}$ the rounded off temperatures are given for the patterns distinguished in Table I.

Species living in the same latitudinal range may show strong differences in temperature preference as they live at different depths, whereas species from different latitudinal belts may show identical temperature ranges as they live at different depths. L. pusillus (Fig. 17, C) and D. metopoclampus (Fig. 17, E) are both subtropical species with comparable north-south ranges, but they differ in temperature preference as they live at different depths. The holo-eurytropical L. photonotus occurs at temperatures where also boreal and temperate species (Fig. $17, F, D, B, C)$ live, due to the different depth strata occupied. Subarctic species usually show daytime temperatures of $4^{\circ}-7^{\circ} \mathrm{C}$, but occasionally they may occur at $10^{\circ} \mathrm{C}$ (Fig. 17). Boreal species prefer temperatures of $7^{\circ}-10^{\circ} \mathrm{C}$. The widespread species like $L$. dofleini normally do not occur in colder waters and show temperature curves for the daytime samples between $8^{\circ}$ and $17^{\circ} \mathrm{C}$ with maxima between $11^{\circ}$ and $15^{\circ} \mathrm{C}$ (Fig. 17).

The geographic separation of provinces is thus difficult, especially when this should also cover the yearly fluctuations. Faunal elements based on literature references, however, can be recognized.

Boreoarctic faunal elements (cf. Hulley, 1984) or subarctic faunal elements (cf. Backus \& Craddock, 1977 ) are $P$. arcticum, B. glaciale, and $N$. kroeyeri. They show high abundances north of $48^{\circ} \mathrm{N}(>5$ specimens, per haul and per hour) and only $B$. glaciale is frequently found up to $38^{\circ} \mathrm{N}$. Except for $P$. arcticum these faunal elements are in spring and

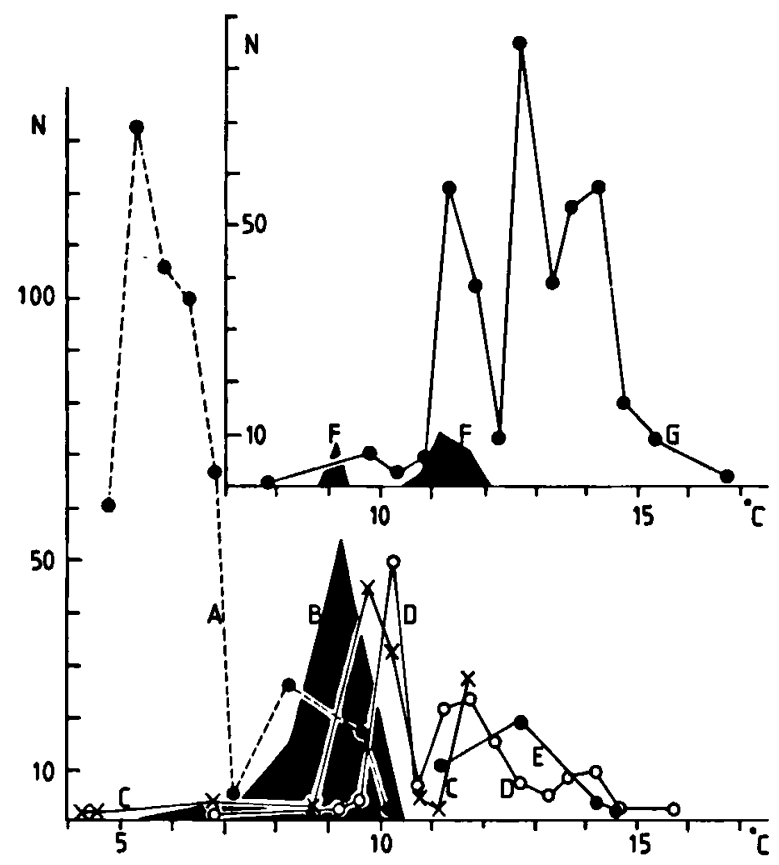

Fig. 17. Temperature preference at daytime depth for: Protomyctophum arcticum (A), Myctophum punctatum (B), Lampanyctus pusillus (C), Diaphus rafinesquei (D), D. metopoclampus (E), Lampanyctis photonotus (F), and Lobianchia dofleini (G); temperature along horizontal, numbers of specimens along vertical axis.

summer found also more southwards, but the centres of their stable ranges are north of $50^{\circ} \mathrm{N}$.

Boreal faunal elements are $M$. punctatum and $L$. crocodilus (cf. Hulley, 1984). N. bolini, though usually considered a temperate-subtropical element, shows the same pattern in the present material as the boreal faunal elements. The last mentioned three species co-occur frequently in low numbers with boreoarctic faunal elements, but the area of most abundant occurrence is around $41^{\circ} \mathrm{N}$ (in spring and summer). This group is found higher north in autumn. The co-occurrence of boreal and boreoarctic faunal elements is thus explained by the southward migration of the latter and the northward migration of the first.

$L$. macdonaldi resembles in distribution $L$. crocodilus and $N$. bolini but it is usually considered a bitemperate faunal element and not a boreal faunal element (cf. Hulley, 1984). In the present material these three species show the greatest abundance between $50^{\circ} \mathrm{N}$ and $41^{\circ} \mathrm{N}$. 
Temperate-subtropical and eurytherm subtropical faunal elements like $D$. rafinesquei, $D$. metopoclampus, $H$. hygomi, L. ater, L. pusillus, and $S$. veranyi could not be separated. They all occur between $29^{\circ} \mathrm{N}$ and $50^{\circ} \mathrm{N}$, with a summer extension to the south and in autumn mainly a migration to the north. A distribution comparable to that of this group is, however, shown by the temperate faunal elements $D$. holti and $L$. intricarius as well; the slightly northward occurrence of these two is not different from the pattern of e.g. L. pusillus and $L$. ater. The widespread species $N$. valdiviae and the holo-eurytropical $G$. coccoi joins the pattern of the temperate-subtropical group.

Northern subtropical faunal elements are $L$. chavesi and $L$. festivus. They occur typically between $29^{\circ} \mathrm{N}$ and $41^{\circ} \mathrm{N}$.

Holo-eurytropical and subtropical faunal elements occur in the present material along the whole transect up to $50^{\circ} \mathrm{N}$, like $L$. gemellari and $B$. indicus. The pattern of these two species is shared by widespread species like $L$. dofleini and $E$. rissoi.

The thermophylous eurytropical faunal elements, like $H$. taaningi, occur south of $29^{\circ} \mathrm{N}$ only.

A group of species occurring along the transect mainly south of $41^{\circ} \mathrm{N}$ is given separately in Table I. This group is dominated by holo-eurytropical faunal elements (L. photonotus, $N$. resplendens, $D$. mollis, C. warmingii, L. rara). B. suborbitale and $L$. lineatus are sometimes considered thermophylous-eurytropical but in the present material they show (Fig. 1) much more the pattern of holoeurytropical faunal elements. The Central water faunal elements $L$. gaussi and $L$. cuprarius join this pattern as well, living between $29^{\circ} \mathrm{N}$ and $38^{\circ} \mathrm{N}$, though incidentally caught more to the north.

C. maderensis resembles the holo-eurytropical faunal elements in distribution but it vicariates clearly with $C$. warmingii so that it can be considered a temperate-subtropical faunal element.

\section{Conclusions}

It was not possible to distinguish provinces with clear borders for the Myctophidae collected in the four seasons. Transitional zones could only be traced between boreoarctic, boreal, subtropical and tropical areas as very broad zones between $48^{\circ} \mathrm{N}$ and $50^{\circ} \mathrm{N}, 41^{\circ} \mathrm{N}$ and $45^{\circ} \mathrm{N}$, and $28^{\circ} \mathrm{N}$ and $37^{\circ} \mathrm{N}$.

Along $30^{\circ} \mathrm{W}$ the boreoarctic faunal elements occur roughly north of $50^{\circ} \mathrm{N}$. The boreal faunal elements occur mainly between $50^{\circ} \mathrm{N}$ and $41^{\circ} \mathrm{N}$, and northern subtropical faunal elements live between about $29^{\circ} \mathrm{N}$ and $41^{\circ} \mathrm{N}$. The temperate faunal elements are in our material frequently mixed with subtropical faunal elements at the latitudes of $29^{\circ} \mathrm{N}$ to $50^{\circ} \mathrm{N}$. Holo-eurytropical and (southern) subtropical faunal elements are found along the whole transect south of $50^{\circ} \mathrm{N}$, while south of $41^{\circ} \mathrm{N}$ mainly holo-eurytropical elements are found together with Central water species. South of $29^{\circ} \mathrm{N}$ the thermophylous eurytropical faunal elements are found.

A seasonal shift of species ranges is evident: the boreal or temperate taxa spread north and southwards in summer, the cold-water elements go southwards in the summer months, and the tropical elements migrate northwards. These shifts obscure faunal borders and the composition of the different faunas, so that in the present material only a small number of species could be clustered in a cold-water and a warm-water group.

The subdivision into sharply delimited faunas and the description of discrete faunal borders is only possible with artificial tools or unacceptable simplifications and cannot be deduced from the original data.

\section{Acknowledgements}

Commanders and crews of HMS "Tydeman" are acknowledged for their non-ceasing help during the sampling programme. Dr. J.E. Badcock is cordially acknowledged for his stimulating advice during collecting of the material; Dr. R.L. Haedrich and Dr. W.L. van Utrecht are kindly acknowledged for their advices with regard to this paper. Drs. I. Sprong and Drs. W.M. Mooy identified part of the 1980 and 1981 material.

\section{References}

Backus, R.H. \& J.E. Craddock, 1977. Pelagic faunal provinces and sound-scattering levels in the Atlantic Ocean. In: N.R. Anderson \& B.J. Zahuranec (eds.), Oceanic sound scattering prediction: 529-547 (Plenum Press, New York/London). 
Backus, R.H., G.W. Mead, R.L. Haedrich \& A.W. Ebeling, 1965. The mesopelagic fishes collected during cruise 17 of the R/V Chain, with a method for analyzing faunal transects. Bull. Mus. comp. Zool. Harv., 134(5): 139-157.

Bleeker, J.\& S. van der Spoel, 1988. Medusae of the Amsterdam Mid North Atlantic Plankton Expeditions (1980-1983) with description of two new species. Bijdr. Dierk., 58(2): 227-258.

Bolin, R.L., 1955. Iniomi: Myctophidae from the "Michael Sars" North Atlantic Deep-Sea Expedition 1910. Rep. scient. Results Michael Sars N. Atlant. Deep-Sea Exped., 4, 2(7): $1-45$.

Gibbs, R.H., R.H. Goodyear, M.J. Keene \& D.W. Brown, 1971. Biological studies of the Bermuda Ocean Acre, II. Vertical distribution and ecology of the lanternfishes (Family Myctophidae). Rep. U.S. Navy Underw. Syst. Centre: 1-141 (Smithson. Inst., Washington).

Halliday, R.G., 1970. Growth and vertical distribution of the Glacier lanternfish, Benthosema glaciale, in the northwestern Atlantic. J. Fish. Res. Bd. Canada, 27(1): 105-116.

Hulley, P.A., 1984. Myctophidae. In: P.J.P. Whitehead, M.-L. Bauchot, J.-C. Hureau, J. Nielsen \& E. Tortonese (eds.), Fishes of the north-eastern Atlantic and Mediterranean, 1 (Clofnam, 58): 429-483 (UNESCO, Paris).

Nafpaktitis, B.G., 1968. Taxonomy and distribution of the lanternfishes, genera Lobianchia and Diaphus, in the North Atlantic. Dana Rep., 73: 1-131.

Nafpaktitis, B.G., 1975. Review of the lanternfish genus Notoscopelus (family Myctophidae) in the North Atlantic and
Mediterranean. Bull. mar. Sci., 25 (1): 75-87.

Nafpaktitis, B.G., R.H. Backus, J.E. Craddock, R.L. Headrich \& B.H. Robinson, 1977. Myctophidae. In: Fishes of the western North Atlantic. Mem. Sears. Fdn. mar. Res., New Haven, 1 (7): 13-287.

Nafpaktitis, B.G. \& J.R. Paxton, 1968. Review of the lanternfish genus Lampadena with a description of a new species. Contr. Sci. Los Angeles, 138: 1-29.

Pafort-van Iersel, G.J.S., 1985. A contribution to pelagic zoogeography of the mid North Atlantic Ocean: 1-21, 97-106, 97-115, 73-96, 1-11, 17-20, 29-36, 1-57, 1-35 (Ph.D. thesis, University of Amsterdam).

Van der Spoel, S., 1981. List of discrete depth samples and open net hauls of the Amsterdam Mid North Atlantic Plankton Expedition 1980 (Project 101A). Bull. zool. Mus. Univ. Amsterdam, 8(1): 1-10.

Van der Spoel, S., 1985. List of discrete depth samples and open net hauls of the Amsterdam Mid North Atlantic Plankton Expeditions 1982 and 1983 (Project 101A). Bull. zool. Mus. Univ. Amsterdam, 10(17): 129-152.

Van der Spoel, S. \& A.G.H.A. Meerding, 1983. List of discrete depth samples and open net hauls of the Amsterdam Mid North Atlantic Plankton Expedition 1981 (Project 101A). Bull. zool. Mus. Univ. Amsterdam, 9(9): 77-91.

Received: 23 October 1990

Revised: 18 January 1991 